\title{
Effects of variable oceanographic conditions on forage fish lipid content and fatty acid composition in the northern California Current
}

\author{
Marisa N. C. Litz $^{1, *}$, Richard D. Brodeur ${ }^{2}$, Robert L. Emmett ${ }^{2}$, Selina S. Heppell ${ }^{3}$, \\ Rosalee S. Rasmussen ${ }^{4}$, Linda O'Higgins ${ }^{1}$, Matthew S. Morris ${ }^{5}$ \\ ${ }^{1}$ Cooperative Institute for Marine Resources Studies, Oregon State University Hatfield Marine Science Center, \\ 2030 Marine Science Dr., Newport, Oregon 97365, USA \\ ${ }^{2}$ Estuarine and Ocean Ecology Program, Northwest Fisheries Science Center, National Oceanic and \\ Atmospheric Administration, Newport, Oregon 97365, USA \\ ${ }^{3}$ Department of Fisheries and Wildlife, 104 Nash Hall, Oregon State University, Corvallis, Oregon 97331, USA \\ ${ }^{4}$ Oregon State University Seafood Research Laboratory, 2001 Marine Dr., Room 253, Astoria, Oregon 97103, USA \\ ${ }^{5}$ Pacific States Marine Fisheries Commission, Point Adams Research Station, Northwest Fisheries Science Center, \\ National Oceanic and Atmospheric Administration, 520 Heceta Place, Hammond, Oregon 97121, USA
}

\begin{abstract}
Lipids and fatty acids (FA) were investigated in 4 species of forage fish: northern anchovy Engraulis mordax, Pacific sardine Sardinops sagax, Pacific herring Clupea pallasi, and whitebait smelt Allosmerus elongatus, for their ability to serve as biological indicators of ocean conditions in the California Current large marine ecosystem (CCLME). Samples were collected during the oceanographically contrasting years of 2005 and 2006. Upwelling was severely curtailed in the spring and early summer of 2005, leading to delayed biological productivity, whereas upwelling was relatively normal in spring 2006. Principal components analysis described $78 \%$ of the variance within the lipid and FA dataset using the first 2 principal components. We found significant intra- and interspecific, interannual, and seasonal differences in lipid and FA profiles using univariate and permutation-based multivariate analysis of variance. Indicator species analysis showed distinct lipid and FA properties associated with each fish species. Using the ratio of docosahexaenoic acid (C22:6n-3) to eicosapentaeonic acid (C20:5n-3), we detected a transition from a diet composed primarily of dinoflagellate origin in early 2005 to a diet resulting from diatom-based productivity by late summer 2006 . This shift was due to interannual differences in primary production, which was confirmed through phytoplankton sampling. Our study demonstrates that lipid and FA biomarkers in the forage fish community can provide information on ocean conditions and productivity that affect food web structure in the CCLME.
\end{abstract}

KEY WORDS: Forage fish · Small coastal pelagics · Lipids · Fatty acids · Bottom-up effects · Warm ocean conditions · EPA · DHA

\section{INTRODUCTION}

In temperate marine ecosystems, environmental variability influences processes of biological productivity, namely by altering the relative abundance of plankton in its community structure. These changes manifest themselves by altering food web structure for a wide range of fishes, birds, and mammals that rely on substantial primary and secondary productivity (Barber \& Chavez 1983, Brodeur \& Pearcy 1992, Brodeur et al. 2006, Sydeman et al. 2006, Trites et al. 2007). Identification of links between forces that affect physical ocean conditions, productivity, and key integrating species that rely on plankton productivity (Peterson \& Keister 2003, El-Sabaawi et al. 2009a) could provide a mechanistic framework for predicting the effects of cli- 
mate change on temperate marine food webs. Likewise, indicators of change in marine trophic dynamics are needed to improve ecosystem-based models that are under development for fisheries management (Fulton et al. 2005). Investigating lipids and fatty acids (FA) in forage fish will provide insight into physiological mechanisms that determine how intra- and interannual changes in the ocean environment alter the availability (to higher trophic levels) of energy from primary production.

Forage fish are key species for evaluating climatemediated changes in prey availability because they are planktivorous and because their population numbers fluctuate between dominant taxa over contrasting environmental periods (Chavez et al. 2003). We examined 4 abundant species of forage fish over $2 \mathrm{yr}$ of contrasting oceanographic conditions and productivity (2005 and 2006) in the northern California Current large marine ecosystem (CCLME). The forage fish were northern anchovy Engraulis mordax, Pacific sardine Sardinops sagax, Pacific herring Clupea pallasi, and whitebait smelt Allosmerus elongatus. Although changes in forage prey quantity have direct effects on predator population dynamics, changes in forage species composition and proximate quality may also influence vital rates such as reproduction and survival (Dalsgaard et al. 2003).

Lipid and FA analyses have been used as biological markers and gauges of diet in marine ecology and constitute an effective tool in food web studies (Iverson et al. 2002, 2004, 2007, 2009, Dalsgaard et al. 2003, Herman et al. 2005, Wang et al. 2009). While FA can be synthesized by forage fish, some (essential fatty acids [EFA]) must be obtained through diet, specifically phytoplankton or herbivorous zooplankton, because they are not biosynthesized at rates required for optimal biological performance (Kainz et al. 2004). Because phytoplankton and herbivorous zooplankton create a wide and unique array of FAs, they provide a suite of biomarkers that can be used to follow specific trophic interactions in marine ecosystems (Sargent et al. 1987, Iverson et al. 1997, 2002, Müller-Navarra et al. 2000, Dalsgaard et al. 2003, Kainz et al. 2004, Budge et al. 2006). Laboratory studies have confirmed that FA composition of fish is affected by their diet (Dalsgaard et al. 2003) and that inter-decadal variability in dietary quality shows a relationship with forage fish productivity (abundance) over long timescales (Litzow et al. 2006).

Phytoplankton production in the CCLME is highly seasonal and varies interannually depending on the onset and intensity of upwelling-favorable conditions (Henson \& Thomas 2007), influencing the quality of food available for forage fish. Two EFAs that serve as biomarkers for altered consumption patterns in planktivorous fish include docosahexaeonic acid
(C22:6n-3, DHA) and eicosapentaeonic acid (C20:5n-3, EPA). DHA is a major FA produced by dinoflagellates, along with polyunsaturated FA (PUFA) containing 18 carbons, specifically octadecapentaenoic acid (C18:5n3 ), whereas EPA is a major FA produced by diatoms. EPA is also abundant in dinoflagellates as a key substrate for the synthesis of DHA via elongation of C20:5n-3 into docosapentaenoic acid (C22:5n-3) and desaturation into DHA. Along with EPA, ingestion of diatoms can be traced by the detection of specific biomarkers with 16 carbons, which are synthesized in the diatom plastid (Graeve et al. 2005). Moreover, DHA, EPA, as well as arachidonic acid (C20:4n-6, ARA) are the major sources of metabolic energy, influencing individual and population growth rates and reproduction (Copeman \& Parrish 2002, Tocher 2003). Because changes in ocean productivity are known to affect the proportion and contribution of diatoms and dinoflagellates to the flow of energy in marine ecosystems, changes in the accumulation of EFA in fishes are expected when a shift in ocean conditions occurs.

The North Pacific Ocean experiences dramatic environmental shifts (Francis \& Hare 1994, Hare \& Mantua 2000, Peterson \& Schwing 2003), but summer 2005 was particularly anomalous, due to delayed upwelling, warm sea-surface temperatures, and decreased productivity lasting through July (Pierce et al. 2006, Schwing et al. 2006, Barth et al. 2007). A shift from diatom (EPA)- to dinoflagellate (DHA)-dominated phytoplankton production was reported throughout the CCLME during this period (Jester et al. 2009) and was linked to several unusual and detrimental changes in higher trophic levels. Forage fish densities, which had been monitored since 1998, decreased dramatically across shelf waters off Oregon and Washington (Emmett et al. 2005, Brodeur et al. 2006, Litz et al. 2008), and numbers of Pacific herring and whitebait smelt were reduced to $10 \%$ of the maximum numbers observed in 2001 (Goericke et al. 2007). Low zooplankton biomass and reduced seabird fecundity were also reported in 2005 (Peterson et al. 2006, Sydeman et al. 2006). By contrast, upwelling in 2006 began at a more normal time, in early May, off Oregon and Washington, but had several relaxation periods and remained weak until late June (Goericke et al. 2007). Recruitment failure during an unusually warm summer spawning season contributed to densities of forage fish in 2005 being the lowest recorded during the National Marine Fisheries Service (NMFS) 9 yr time series ending in 2006. However, upwelling intensified from July through September 2006, resulting in elevated diatom and chlorophyll a concentrations, copepod biomass, and euphausiid egg abundances (Goericke et al. 2007).

Contrasting ocean conditions during the summers of 2005 and 2006 provided an excellent framework for 
examining links between rapidly changing ocean conditions and the biological productivity of forage fish off the Oregon and Washington coast. Our objectives in the present study were to: (1) measure total lipids in 4 major forage fish species of the CCLME during contrasting oceanographic conditions; (2) compare intraspecific, interspecific, seasonal, and interannual patterns of lipid and forage fish FA composition; (3) identify specific lipid and FA indicators associated with each forage fish sampled; and finally (4) examine the applicability of forage fish lipids and FA to serve as biomarkers of ocean productivity. We hypothesize that changes in lipid and FA levels of forage fish species are related to changes in oceanographic conditions. A better understanding of changes in forage fish lipid composition mediated by variations in oceanographic conditions will provide a useful tool for evaluation of the forage base for a wide range of economically important fish species and top predators such as seabirds and mammals.

\section{MATERIALS AND METHODS}

Identification and enumeration of the phytoplankton community. Surface-water samples were collected using a bucket during sampling cruises to a baseline station 5 nautical miles $(9 \mathrm{~km})$ off Newport, Oregon, USA (NH05). Cruises were conducted approximately biweekly, from 11 May to 28 September 2005 and from 3 May to 12 October 2006 (Fig. 1). Samples were preserved with a few drops of acidified Lugol's iodine, and, where possible, both phytoplankton and microzooplankton were identified to species using a Wild M40 inverted microscope at $200 \times$ magnification. Cells were enumerated using the technique described in von Utermöhl (1931), and estimates of phytoplankton biomass (standardized to $\mathrm{mg} \mathrm{C} \times \mathrm{m}^{-3}$ ) were calculated for each species according to Kovala \& Larrance (1966). We identified 74 species of diatoms, 73 species of dinoflagellates, 3 species of flagellates, and 5 species of planktonic ciliates. Sea-surface temperature (SST, measured at a depth of $3 \mathrm{~m}$ ) was recorded during each sampling event by deploying a Sea-bird SBE 19 SeaCat conductivity, temperature and depth (CTD) profiler. In addition, we collected chlorophyll a ( $\mathrm{chl} a \mu \mathrm{g} \mathrm{l}^{-1}$ ) from the water at $3 \mathrm{~m}$ depth on Whatman GF/C glass microfiber filters. We treated chlorophyll samples with acetone and measured them with a Turner Designs 10-AU fluorometer. Average phytoplankton biomass, chl a concentration, and SST from May through July $2005(\mathrm{n}=4)$ and $2006(\mathrm{n}=4)$ represent early summer sampling periods. Averages from August through September $2005(\mathrm{n}=7)$ and August through 12 October $2006(\mathrm{n}=4)$ represent late summer sampling periods.

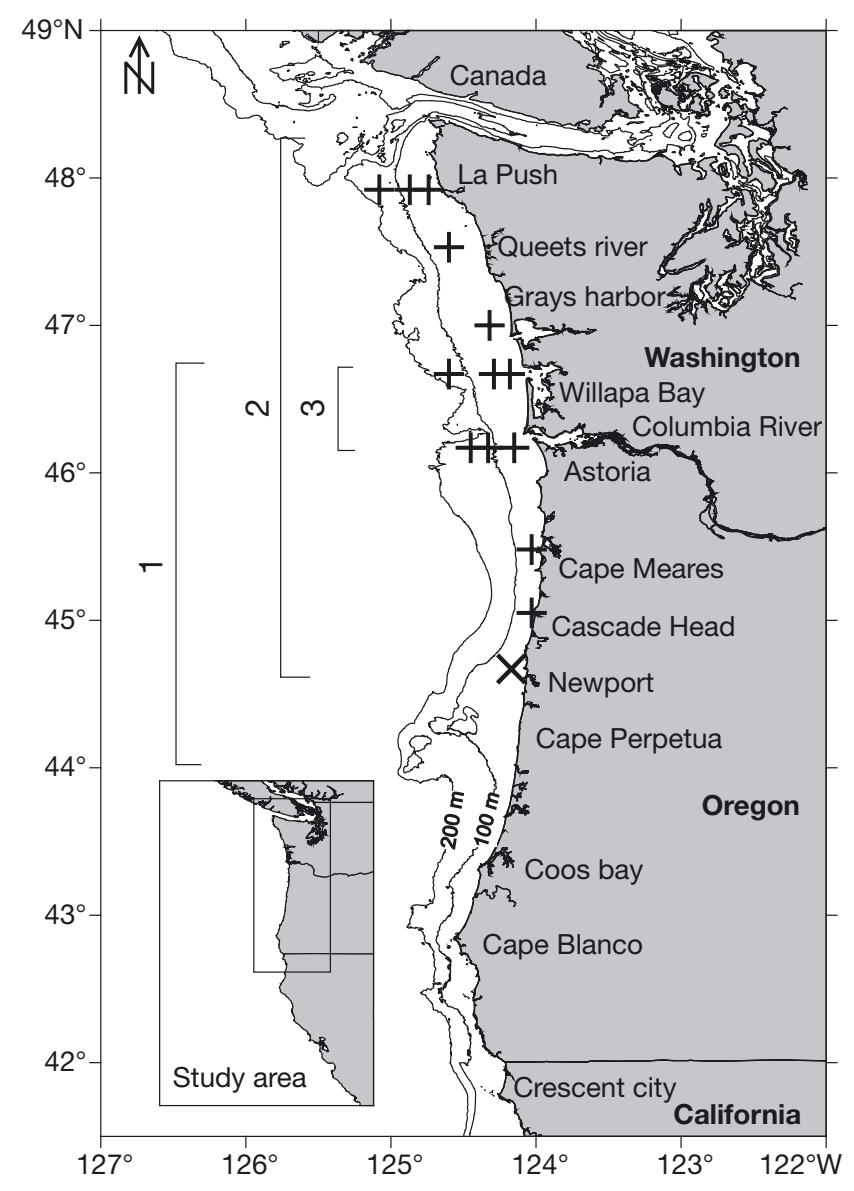

Fig. 1. Study area and sampling locations in the present study. Fish (+) were caught during the following National Marine Fisheries Service fishery-independent studies: (1) Stock Assessment Improvement Project, (2) Bonneville Power Administration Plume Study, and (3) Predator Study. Phytoplankton ( $x$ ) collections occurred at a baseline station 5 nautical miles $(9 \mathrm{~km})$ off Newport, Oregon, USA (NH05). Also shown are 100 and $200 \mathrm{~m}$ isobaths

Forage fish collection. We identified total lipid content and FA composition from 160 forage fish of the following 4 species: northern anchovy Engraulis mordax, Pacific sardine Sardinops sagax, Pacific herring Clupea pallasi, and whitebait smelt Allosmerus elongatus. Collections occurred off Oregon and Washington in early and late summer 2005 and 2006 during NMFS fishery-independent surveys conducted between 14 June and 21 September 2005 and 27 May and 26 September 2006 (Fig. 1). These surveys included Bonneville Power Administration Plume Study cruises (Brodeur et al. 2005), Predator Study cruises (Krutzikowsky \& Emmett 2005, Emmett et al. 2006), and Stock Assessment Improvement Plan cruises (Phillips et al. 2007). Collection stations ranged from 2 to $40 \mathrm{~km}$ offshore and from 45 to $48^{\circ} \mathrm{N}$ latitude. All fish were cap- 

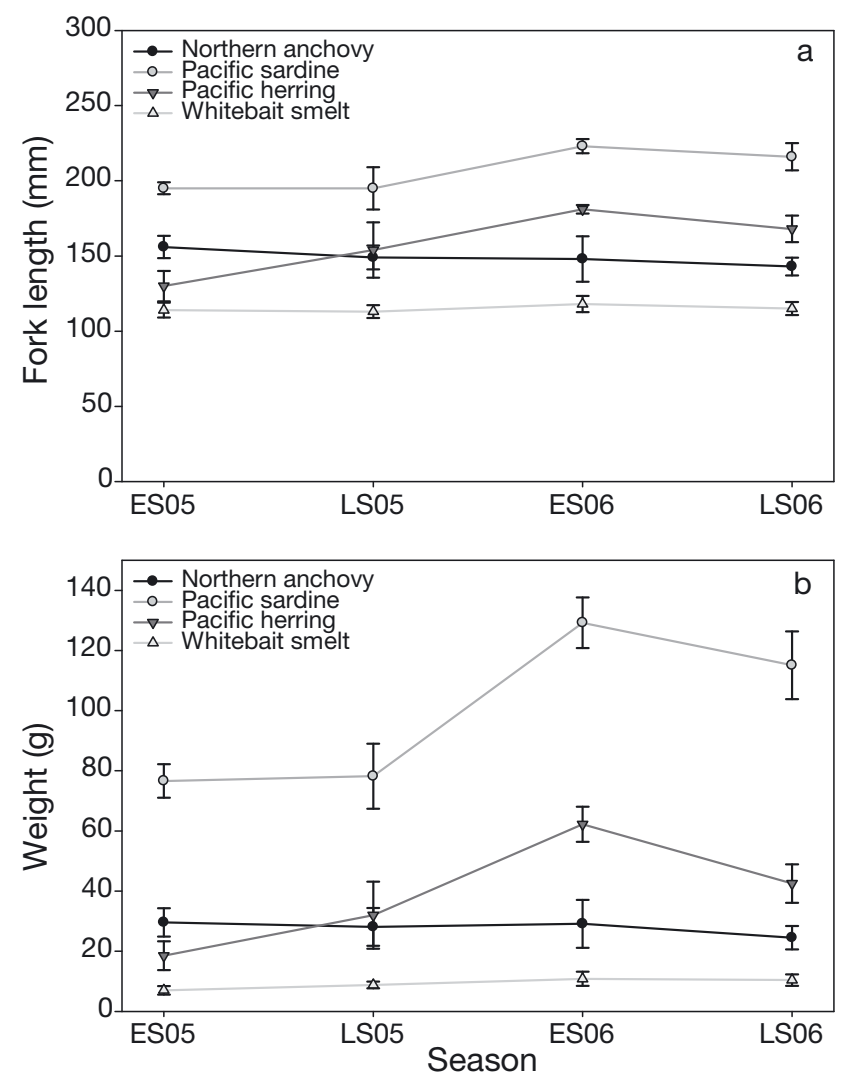

Fig. 2. Engraulis mordax, Sardinops sagax, Clupea pallasi and Allosmerus elongatus. Mean \pm SD (a) fork length $(\mathrm{mm})$ and $(\mathrm{b})$ weight $(\mathrm{g})$ of the 4 species of forage fish $(\mathrm{n}=10$ species $^{-1}$ ) used in the present study: northern anchovy, Pacific sardine, Pacific herring, and whitebait smelt. Forage fish were sampled during early and late summer 2005 and 2006 (ES05, LS05, ES06, and LS06)

tured using a Nordic 264-rope trawl (NET Systems) fished behind the vessel at surface or midwater depths ( 30 to $50 \mathrm{~m}$ depth stratum) for tow durations of 15 to 30 min. Fish to be used for lipid and FA analysis were randomly selected, measured (fork length; FL), and weighed (Fig. 2). Samples were sorted into air-tight plastic bags and frozen immediately at $-20^{\circ} \mathrm{C}$ for transport to the laboratory. In the laboratory, fish were stored at $-80^{\circ} \mathrm{C}$ until analysis to prevent oxidation.

Laboratory analyses. Lipids were extracted from homogenates of fish in accordance with Folch et al. (1957), as modified by Parrish (1999) and Budge et al. (2006), using 2:1 chloroform/methanolat 20 to 30 parts solvent to tissue. A subsample of 0.5 to $1.5 \mathrm{~g}$ was used for analysis. The weight of the lipid (g) was recorded, and the proportion of total lipid present in the subsample was calculated. Fatty acid methyl esters (FAME) were prepared using an acidic transesterification (boron trifouride) modified from the Association of Official Analytical Chemists (AOAC) method 991.39
(AOAC 1998). FAMEs were quantified using a gas chromatograph (GC, Shimadzu GC-2010, Shimadzu Corp.), equipped with a flame-ionization detector and capillary column (Omegawax 250 capillary column, $30 \mathrm{~m} \times 0.25 \mathrm{~mm} \times 0.25 \mu \mathrm{m}$ film thickness, Supelco). We used the following parameters for the gas chromatograph system: injector and detector temperatures of 250 and $270^{\circ} \mathrm{C}$, respectively; column temperature of $170^{\circ} \mathrm{C}$ with an $8 \mathrm{~min}$ hold time; gradual heating to $245^{\circ} \mathrm{C}$ at a rate of $1^{\circ} \mathrm{C} \mathrm{min}{ }^{-1}$ with a 2 min hold time, and helium as a carrier gas. FAs were identified, and their concentrations were calculated by comparing their retention times with those of the reference standards (37-component FAME mix and C22:5n-3 standard, Supelco) according to AOAC method 991.39 (AOAC 1998, Okada \& Morrissey 2007).

Statistical analyses. We employed the S-Plus 6.2 software package (Insightful) for all parametric statistical analyses, and used PC-ORD (MjM Software Design) for all nonparametric multivariate analyses. Lipid results are based on mean \% wet weight $( \pm \mathrm{SD})$ of a subsample of 10 fish for each species and location over time. FAs are presented as mean mass percent of total FA $( \pm \mathrm{SD})$ from replicated runs on the GC for 3 individual fish from each species during each of the 4 sampling periods. We made intraspecific comparisons of total whole lipids and individual FAs by sampling period using analysis of variance (ANOVA). To compare means when results of ANOVA were significantly different, Tukey's pairwise honestly significant difference (HSD) post hoc tests $(\alpha=0.05)$ were conducted after confirmation of normality and equal variance.

Fifteen lipid and FA components were selected as relevant variables in our exploration of food web relationships and physiological processes, and comprised our multivariate dataset. They were selected based on their ability to serve as dietary biomarkers (Copeman \& Parrish 2002, El Sabaawi et al. 2009b) and included all FAs that constituted $>1.0 \%$ of total FA, as well as the EFA ARA. The biomarkers selected were myristic acid (C14:0), palmitic acid (C16:0), palmitoleic acid (C16:1n-7), stearic acid (C18:0), oleic acid (C18:1n-9), eicosenoic acid (C20:1n-9), ARA, EPA, C22:5n-3, DHA, the sum of measured saturated, monounsaturated, and polyunsaturated FAs ( SFA, $\Sigma$ MUFA, and $\Sigma$ PUFA, respectively), together with DHA/EPA, and the mean percent (wet weight) of total lipids measured for each fish during the 4 sampling periods.

Interspecific differences were evaluated with principal components analysis (PCA) combined with indicator species analysis (ISA). PCA was used to simplify the multivariate dataset by transforming correlated variables into a set of uncorrelated principal components. This allowed a display of major trends within the dataset without significant loss of total original varia- 
tion. ISA combines information on the concentration of species abundance and the reliability of species occurrence in a particular group (Dufrêne \& Legendre 1997). If lipid components are conceptualized as groups of sample units, the method of calculating species indicator values combines information on the concentration of species abundance in a particular group of lipid components and the faithfulness of occurrence of a species in that particular group to produce indicator values for each species (McCune \& Grace 2002). In the present study, statistical significance of each group was examined by 4999 runs of a Monte Carlo simulation. The level of significance depended on the proportion of randomized trials with an indicator value equal to or exceeding the observed indicator value.

In addition to PCA, we evaluated interspecific variation in lipid and FA composition using 1-way permutation-based nonparametric multivariate analysis of variance (NPMANOVA). NPMANOVA relies on comparing the observed value of a test statistic (pseudo F-ratio) against a recalculated test statistic generated from random re-ordering (permutation) of the data (Anderson 2001). One advantage of the permutation approach is that the resulting test is 'distribution free' and not constrained by many of the typical assumptions of parametric statistics. We used a non-Euclidean distance measure in our calculations. We also used 2-way factorial NPMANOVA to test for seasonal and interannual differences in lipid content and FA composition for all species combined. Finally, we tested for relationships between DHA and EPA concentrations and total lipid content for all forage species, with EFA values log-transformed to assure normality and equal variance.

\section{RESULTS}

\section{Phytoplankton biomass and ocean temperature}

Mean diatom biomass was estimated at $186.5 \pm 161.2 \mathrm{mg} \mathrm{C} \mathrm{m}^{-3}$ during early summer 2005 and nearly doubled to $340.4 \pm 590.9 \mathrm{mg} \mathrm{C} \mathrm{m}^{-3}$ in early summer 2006 (Fig. 3). Conversely, mean dinoflagellate biomass was estimated at $63.0 \pm 111.5 \mathrm{mg} \mathrm{C} \mathrm{m}^{-3}$ in early summer 2005, but was considerably lower in early summer 2006, at $12.7 \pm$ $17.5 \mathrm{mg} \mathrm{C} \mathrm{m}^{-3}$ (Fig. 3). Diatoms, mainly
Guinardia spp. and Thallasiosira spp., were more abundant, averaging $300.2 \pm 464.5 \mathrm{mg} \mathrm{C} \mathrm{m}^{-3}$, compared to dinoflagellates, mainly Prorocentrum spp. and Gyrodinium spp., which averaged $22.2 \pm 50.9 \mathrm{mg} \mathrm{C} \mathrm{m}^{-3}$ during all sampling periods. However, on 6 July 2005, a sampling date that fell during our early summer 2005 sampling schedule, dinoflagellate biomass (230.2 mg C $\mathrm{m}^{-3}$ ) was double that of diatoms (116.0 $\left.\mathrm{mg} \mathrm{C} \mathrm{m}^{-3}\right)$. On 6 July 2005, we also observed the highest $\operatorname{SST}\left(15.9^{\circ} \mathrm{C}\right)$ and the lowest measured $\mathrm{chl}$ a concentration $(0.05 \mu \mathrm{g}$ $\mathrm{l}^{-1}$ ), of all sampling periods.

\section{Forage fish lipid content}

Total lipid content ( $\%$ wet weight) of individual forage fish over collections ranged from 0.4 to $26.4 \%$. Mean lipids $( \pm$ SD) across all sampling periods measured $5.3 \pm 3.7 \%$ for northern anchovy Engraulis mordax, $16.3 \pm 5.9 \%$ for Pacific sardine Sardinops sagax, $4.9 \pm 3.6 \%$ for Pacific herring Clupea pallasi, and $4.9 \pm$ $1.7 \%$ for whitebait smelt Allosmerus elongatus. Pacific sardine contained the highest amounts of lipids over all sampling periods, whereas northern anchovy lipids
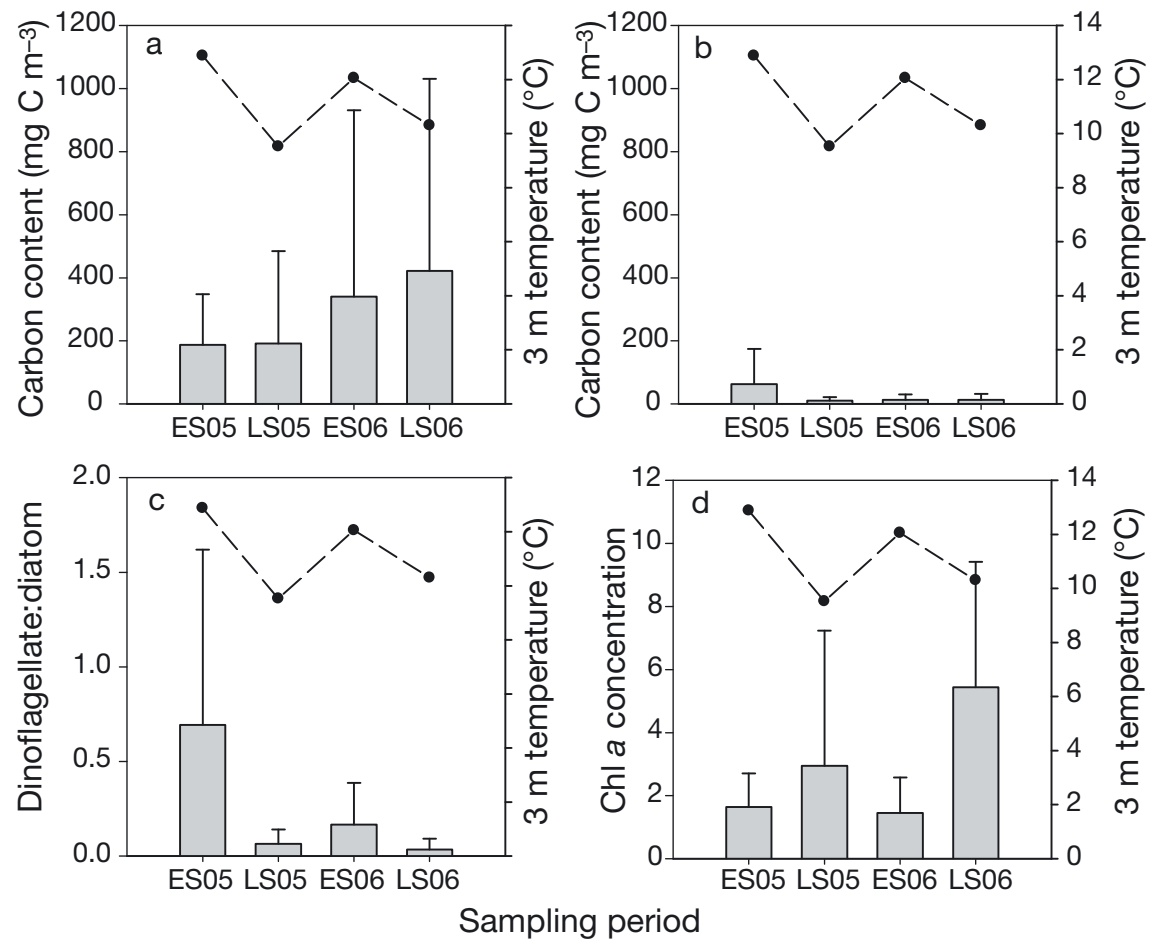

Fig. 3. Mean $( \pm \mathrm{SD})$ phytoplankton biomass $\left(\mathrm{mg} \mathrm{C} \mathrm{m}^{-3}\right)$ measured for (a) diatoms and (b) dinoflagellates during early and late summer 2005 and 2006 (ES05, LS05, ES06, and LS06). Also shown are (c) the ratio of dinoflagellates to diatoms and $(\mathrm{d})$ mean chlorophyll a ( $\mathrm{chl}$ a) concentration $\left(\mu \mathrm{g} \mathrm{l}^{-1}\right)$. Mean sea-surface temperature $\left({ }^{\circ} \mathrm{C}\right.$ ) measured at $3 \mathrm{~m}$ depth during each phytoplankton sampling event is overlaid on each plot (dashed line) 
were lowest during early summer and whitebait smelt were lowest during late summer periods. We found significant intraspecific differences in total lipid content among seasons (Appendix 1). In fact, mean northern anchovy, Pacific sardine, and Pacific herring lipids were significantly lower (ANOVA and Tukey's HSD, $\mathrm{p}<0.05$ ) during the anomalously warm, poor upwelling period of early summer 2005 than during any other sampling period $(0.9 \pm 0.6,8.2 \pm 2.6$, and $3.1 \pm$ $2.6 \%$, respectively). In late summer 2005, whitebait smelt lipids were significantly lower than during any other sampling period $(2.6 \pm 1.1 \%$, ANOVA and Tukey's HSD, p < 0.05), while northern anchovy lipids were significantly higher $(9.7 \pm 2.3 \%$, ANOVA and Tukey's HSD, p < 0.05). In early summer 2006, northern anchovy, Pacific sardine, and Pacific herring lipids were significantly higher (ANOVA and Tukey's HSD, $\mathrm{p}<0.05)$, than their lipid profiles during early summer $2005(4.9 \pm 1.6,20.4 \pm 4.5$, and $7.6 \pm 4.6 \%$, respectively, Appendix 1a-c).

\section{Fatty acid profiles}

Major FA compositions of total lipids for each forage fish species during all 4 sample periods are presented in Appendix 1. Twenty-five FAs were identified for each species. High, but variable proportions of n-3 PUFA (EFA), specifically EPA and DHA, were present in all forage fish lipids. The most abundant FAs generally included C14:0, C16:0, C16:1n-7, C18:0, C18:1n-9, EPA, and DHA. Differences in individual FAs were observed for each species by sampling period (Appendix 1). In general, we measured significant increases (ANOVA and Tukey's HSD, p < 0.05) in $\Sigma$ SFA and $\Sigma$ MUFA between early and late summer for all species (except $\Sigma$ SFA in whitebait smelt and $\Sigma$ MUFA in Pacific sardine) and significant decreases in $\Sigma$ PUFA between early and late summer for all species except whitebait smelt (Appendix 1).

\section{Saturated fatty acids}

SFA concentrations are noted as being a source of potential metabolic energy in fish during growth and/or spawning. Mean $\Sigma$ SFA accounted for 38.1 to $42.8 \%$ of northern anchovy FA composition (Appendix 1a), with C16:0 the most abundant saturate, significantly decreasing (ANOVA and Tukey's HSD, p < 0.05) from $29.3 \%$ in early summer 2005 to $22.3 \%$ in early summer 2006. Similarly, mean SFA accounted for 39.9 to $43.2 \%$ of total Pacific sardine FA, 33.0 to $37.9 \%$ of total FA in Pacific herring, and 34.0 to $41.7 \%$ in whitebait smelt, each with C16:0 being the most abun- dant SFA (Appendix 1b-d). Other SFAs of relative high abundance in all forage fish were C14:0, which significantly increased (ANOVA and Tukey's HSD, p < 0.05) in abundance from 2005 to 2006 in all fish but Pacific sardine, and C18:0, which significantly increased in abundance from 2005 to 2006 in all fish but northern anchovy (Appendix 1).

\section{Monounsaturated fatty acids}

¿MUFA constituted anywhere from 15.1 to $43.3 \%$ of total FAs, demonstrating considerable interannual and seasonal variability, especially among Pacific herring and whitebait smelt (Appendix 1c,d). In northern anchovy, $\Sigma$ MUFA were less abundant than in any other forage fish species, significantly increasing (ANOVA and Tukey's HSD, p < 0.05) from $16.5 \%$ of all FAs in early summer 2005 to $22.2 \%$ in early summer 2006 (Appendix 1a). By contrast, mean whitebait smelt ¿MUFA equaled 32.0 and $32.7 \%$ during the same 2 periods, respectively (Appendix 1d). In all species, C16:1n-7 and C18:1n-9 were the most abundant MUFAs present (Appendix 1a-d). However, during early summer 2006, MUFAs with 20 or 22 carbons, like C20:1n-9 and erucic acid (C22:1n-9), were present in significantly higher (ANOVA and Tukey's HSD, p < 0.05) amounts of Pacific herring lipids than during any other sampling period (11.0 and $12.9 \%$, respectively; Appendix 1c).

\section{Polyunsaturated fatty acids}

Because PUFAs include EFA obtainable only through diet, this group varied the most among sampling periods, as predicted, given the variable levels of ocean productivity observed between 2005 and 2006 . IPUFA content ranged from 23.0 to $50.2 \%$ of total FAs in all species sampled. PUFA concentrations significantly decreased (ANOVA, p < 0.05) from 2005 to 2006 for Pacific herring and whitebait smelt and significantly decreased from early to late summer in 2005 in all species except whitebait smelt. However, there were no significant intra-specific seasonal differences in SPUFA concentrations in 2006 (Appendix 1). We observed considerable seasonal shifts in relative contributions of EPA and DHA to total PUFA composition, particularly in northern anchovy (Appendix 1a). Northern anchovy EPA concentrations in early summer rose significantly (ANOVA and Tukey's HSD, p < 0.05 ) from $10.0 \%$ in 2005 to $20.1 \%$ in 2006 , while DHA contributions significantly declined from 27.4 to $11.3 \%$ during the same 2 periods (Appendix 1a). EPA concentrations significantly declined in late summer from 
2005 to 2006 for Pacific herring, ranging from 12.3 to $10.6 \%$. In direct comparison, Pacific herring DHA concentrations also declined in late summer from 2005 $(21.1 \%)$ to $2006(10.2 \%)$ and were highly significant (ANOVA and Tukey's HSD, p < 0.01; Appendix 1c). Similarly, whitebait smelt DHA concentrations significantly declined in late summer from 2005 (18.3\%) to 2006 (9.4\%; Appendix 1d). Ratios of DHA to EPA are commonly used to distinguish dinoflagellate from diatom productivity and are shown in Appendix 1. DHA/EPA values were significantly larger (ANOVA and Tukey's HSD, p < 0.05) in northern anchovy (2.8) and Pacific herring (2.6) during early summer 2005 than during any other sampling period (Appendix 1a,c). Other EFAs of particular concern to the forage fish sampled, although occurring at low levels ( 0.3 to $2.5 \%$ of total FAs) were PUFAs containing 18 carbons: linoleic acid (C18:2n-6, LA), $\gamma$-linolenic acid (C18:3n-6, GLA), and $\alpha$-linolenic acid (C18:3n-3, ALA; Appendix 1).
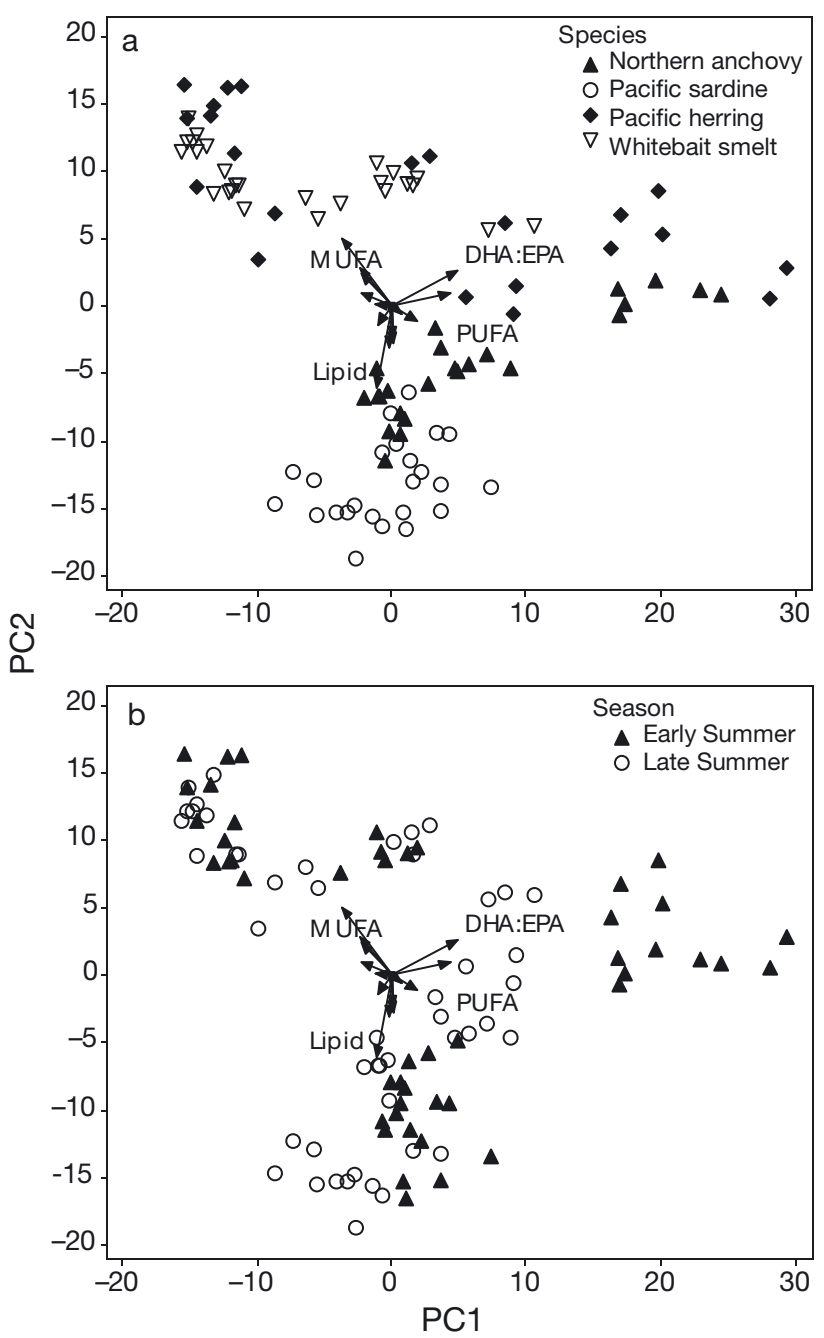

\section{Community analyses}

PCA identified the majority of interspecific, seasonal, and interannual variances in the multivariate dataset using 15 lipid content and FA variables from the 4 forage fish species sampled. The first 2 principal components (PCs) accounted for $78.3 \%$ of the total variance in lipid content and FA composition (Fig. 4). PC1 accounted for $49.7 \%$ of the variance and separated DHA, C16:0, EPA, and lipid content, which loaded positively onto the axis, from C18:0 and LMUFA, which loaded negatively onto the axis. PC2 accounted for $28.6 \%$ of the variance and separated DHA, $\Sigma$ MUFA, and ¿PUFA, which loaded positively onto the axis, from lipid content, EPA, and $\Sigma$ SFA, which loaded negatively onto the axis.

Each lipid and FA component showed a significant association within a specific forage fish species (i.e. each fish species had a distinctive lipid/FA signature). ISA determined that northern anchovy was signifi-

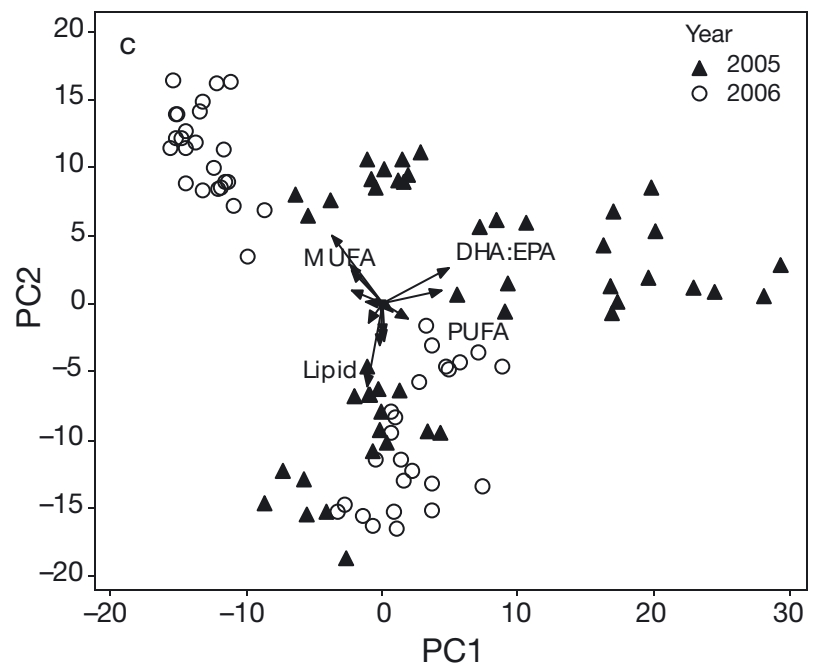

Fig. 4. Principal component analysis of lipid data showing the first 2 principal components (PC1 and PC2) organized by (a) species: northern anchovy Engraulis mordax, Pacific sardine Sardinops sagax, Pacific herring Clupea pallasi, and whitebait smelt Allosmerus elongatus, (b) season: early and late summer, and (c) year: 2005 and 2006. The fatty acid parameters used were: C14:0, C16:0, C16:1n-7, C18:0, C18:1n-9, C20:1n-9, C20:4n-6 (ARA), C20:5n-3 (EPA), C22:5n-3, C22:6n-3 (DHA), DHA/EPA, and the sum of saturated fatty acids ( $\Sigma$ SFA), monounsaturated fatty acids ( MUFA), polyunsaturated fatty acids ( $\mathrm{PUFA}$ ), as well as lipid weight (\% wet mass) 
cantly associated with $\Sigma$ PUFA $(\mathrm{p}<0.01)$ and the saturate C16:0 values ( $p<0.01$; Table 1 , Fig. 4 ). Pacific sardine was strongly associated with values of total lipid content ( $\mathrm{p}<0.01)$, but also with $\Sigma$ SFA, C22:5n-3, C14:0, and the EFAs EPA and ARA (all with $\mathrm{p}<0.01$; Table 1, Fig. 4). Pacific herring was associated with levels of

Table 1. Engraulis mordax, Sardinops sagax, Clupea pallasi and Allosmerus elongatus. Indicator species analysis evaluating northern anchovy, Pacific sardine, Pacific herring, and whitebait smelt associations with 15 lipid and fatty acid parameters. SFA: saturated fatty acids (FA); MUFA: monounsaturated FA: PUFA: polyunsaturated FA; ARA: arachidonic acid;

EPA: eicosapentaeonic acid; DHA: docosahexaeonic acid

\begin{tabular}{|c|c|c|c|}
\hline Parameter & $\begin{array}{l}\text { Indicator } \\
\text { value }\end{array}$ & $\mathrm{p}$ & Group \\
\hline C14:0 & 30.9 & $<0.01$ & Pacific sardine \\
\hline C16:0 & 27.6 & $<0.01$ & Northern anchovy \\
\hline C18:0 & 33.9 & $<0.01$ & Whitebait smelt \\
\hline $\mathrm{C} 16: 1 \mathrm{n}-7$ & 29.4 & $<0.01$ & Whitebait smelt \\
\hline C18:1n-9 & 41.7 & $<0.01$ & Whitebait smelt \\
\hline C20:1n-9 & 49.3 & $<0.01$ & Pacific herring \\
\hline C20:4n-6 (ARA) & 33.6 & $<0.01$ & Pacific sardine \\
\hline C20:5n-3 (EPA) & 33.1 & $<0.01$ & Pacific sardine \\
\hline$C 22: 5 n-3$ & 37.3 & $<0.01$ & Pacific sardine \\
\hline C22:6n-3 (DHA) & 30.7 & 0.02 & Pacific herring \\
\hline$\Sigma \mathrm{SFA}$ & 26.8 & $<0.01$ & Pacific sardine \\
\hline$\Sigma$ MUFA & 31.2 & $<0.01$ & Whitebait smelt \\
\hline ¿PUFA & 27.6 & $<0.01$ & Northern anchovy \\
\hline DHA/EPA & 33.9 & 0.01 & Pacific herring \\
\hline Lipid & 52.2 & $<0.01$ & Pacific sardine \\
\hline
\end{tabular}

Table 2. Permutation-based nonparametric multivariate analysis of variance evaluating species effects using a 1-way design and seasonal, year and the interaction of season and year effects using a 2-way factorial design, both analyses on 15 lipid and fatty acid parameters: C14:0, C16:0, C16:1n-7, C18:0, C18:1n-9, C20:1n-9, C20:4n-6 (ARA), C20:5n-3 (EPA), C22:5n-3, C22:6n-3 (DHA), DHA/EPA, and total saturated, monounsaturated, and polyunsaturated fatty acids, as well as lipid weight (\% wet mass). For both tests, statistical significance was based on 4999 Monte Carlo randomizations. All relationships resulted in $\mathrm{p}$-values $\leq 0.02$

\begin{tabular}{|lccccc|}
\hline Source & df & SS & MS & Pseudo $F$ & $t$ \\
\hline One-way design & & & & & \\
Species & 3 & 2.36 & 0.79 & 26.59 & \\
Residual & 92 & 2.72 & 0.03 & & \\
Total & 95 & 5.07 & & & \\
Comparison & & & & & 4.47 \\
Northern anchovy vs. Pacific sardine & & & & & 3.99 \\
Northern anchovy vs. Pacific herring & & & & & 6.49 \\
Northern anchovy vs. whitebait smelt & & & & & 5.56 \\
Pacific sardine vs. Pacific herring & & & & & 8.40 \\
Pacific sardine vs. whitebait smelt & & & & & 2.72 \\
Pacific herring vs. whitebait smelt & & & & & \\
Two-way factorial design & 1 & 0.17 & 0.17 & 3.71 & \\
Season & 1 & 0.57 & 0.57 & 12.61 & \\
Year & 1 & 0.15 & 0.15 & 3.25 & \\
Season $\times$ Year & 92 & 4.18 & 0.05 & & \\
Residual & 95 & 5.07 & & & \\
Total & & & & & \\
\hline
\end{tabular}

DHA/EPA ( $p=0.01)$, but also with DHA $(p=0.02)$ and the MUFA C20:1n-9 ( $p<0.01$; Table 1, Fig. 4). Whitebait smelt was associated with levels of $\Sigma$ MUFA, particularly C18:1n-9 and C16:1n-7, but also with the saturate C18:0 (all p < 0.01; Table 1, Fig. 4).

Test results from NPMANOVA analyses revealed unequivocal effects of species, season, year, and season $\times$ year on lipid and FA composition in all forage species sampled (Table 2). All species sampled had significantly different lipid and FA profiles ( $p<0.01)$, but the most significant difference was between Pacific sardine and whitebait smelt (Table 2). Whitebait smelt Pacific herring lipid and FA profiles, although also nificantly different ( $p<0.01)$, varied the least all species sampled (Table 2a). These analyshowed that the effect of year $(p<0.01)$ was greater tion of season and year $(p=0.02)$. This nonparametric approach allowed sizes of effects to be compared directly through partitioning of variation and examination of mean squares.

\section{Relationship between lipids and EFAs}

Quantitative mean (\% FA mass) values of DHA and EPA were significantly related to total lipid (\% wet mass) content (Fig. 5) for all forage fish sampled. Regression models with lipid content as the explanatory variable and essential FA as the response variable showed that lipid had a significant effect on both DHA $\left(\mathrm{r}^{2}=0.38, F_{1,14}=8.55, \mathrm{p}=0.01\right)$ and EPA composition $\left(\mathrm{r}^{2}=0.41, F_{1,14}=\right.$ 9.84, $\mathrm{p}<0.01)$. We found that DHA decreased exponentially (Fig. 5a) as a function of total lipid content across species, while EPA increased (Fig. 5b).

\section{DISCUSSION}

Interannual differences in forage fish total lipid and FA profiles are the result of oceanographic conditions. Late upwelling/biological transition in the CCLME in 2005 affected phytoplankton productivity, zooplankton, and forage fish abundance, and seabird recruitment during 2005 (Mackas et al. 2006, Peterson et al. 2006, Sydeman et al. 2006, Goericke et al. 2007, Jester et al. 2009). In early summer 2005 , forage fish in our study area had diets comprised almost exclusively of 

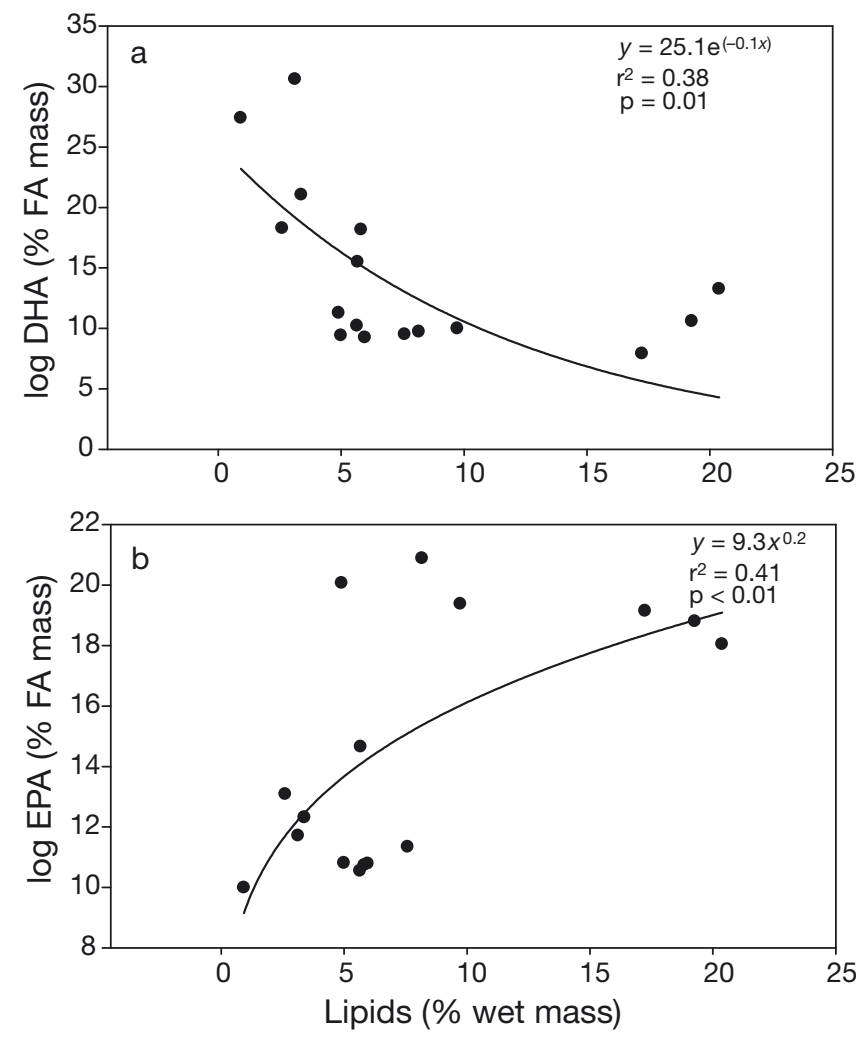

Fig. 5. Relationship between total lipid content (\% wet mass) and essential fatty acid content (\% FA mass) for (a) docosahexaenoic acid (C22:6n-3, DHA) and (b) eicosapentaenoic acid (C20:5n-3, EPA). Each point represents a mean for a species and collection period

dinoflagellates, or of dinoflagellate origin, as identified by high DHA/EPA ratios (Appendix 1). Dinoflagellates/flagellates are characterized by high DHA levels, and also by the presence of 18-carbon chain PUFAs, including the following EFAs: LA, GLA, and ALA (Thompson et al. 1992, Graeve et al. 1994, 2005, St John et al. 2001, El-Sabaawi et al. 2009b). Fewer secondary producers (e.g. copepods and euphausiids) were likely consumed in 2005, as evidenced by lower C20 and C22 MUFA signatures compared to those in 2006 (Appendix 1; Dalsgaard et al. 2003). The lowest lipid values recorded for any species was northern anchovy Engraulis mordax in early summer 2005 (Appendix 1a), a period which coincided with the highest measured SST, greatest dinoflagellate biomass (Fig. 2), and the highest DHA/EPA ratio. One caveat is that these ratios are most effectively used as diet biomarkers in strictly herbivorous species (which these species are not), and must be regarded with caution (Fraser et al. 1989, Müller-Navarra et al. 2000, Dalsgaard et al. 2003, Kainz et al. 2004). Nonetheless, the effects of poor oceanographic conditions in 2005 on forage fish lipids was obvious, as lipids were also low- est in Pacific sardine Sardinops sagax and Pacific herring Clupea pallasi in 2005 (Appendix 1b-c).

CCLME oceanographic conditions improved dramatically in summer 2006 from conditions the year before. Upwelling and copepod biomass rebounded to values twice those observed in 2005 (Goericke et al. 2007). In 2006, the diets of forage fish in the present study shifted to more grazing on diatoms, observable through the increased proportion of C16:1n-7 from early summer 2005 to all other periods (Appendix 1) and particularly through the decreased DHA/EPA ratios. Diatoms are characterized by high concentrations of EPA, C16:1n-7, and also by the presence of 16carbon chain PUFAs (which were unidentifiable based on our reference FAME standards). Greater diatom feeding in 2006 coincided with higher estimates of phytoplankton biomass (Fig. 3) at the southern range of our fish sampling area, which were larger throughout 2006 than at any time during 2005. Plankton sampling along the Newport Hydrographic transect is extremely reliable at tracking changes in ocean and climate conditions of the northern California Current System (Peterson \& Keister 2003, Peterson \& Schwing 2003, Hooff \& Peterson 2006) and appropriately represents the area represented by the present study. The highest lipid values of any species were recorded for Pacific sardine in early summer 2006 (Appendix 1b), a period that coincided with larger sardine weights (Fig. 3) than during any sampling period in 2005. Lipid values for Pacific herring and whitebait smelt Allosmerus elongatus were also the highest in early summer 2006 (Appendix 1c,d).

Intraspecific differences were apparent within all forage fish species sampled (Appendix 1). Withinspecies variability is important to consider because it allows us to characterize species patterns and clarify oceanographic influences on lipid and FA composition. One factor contributing to intraspecific differences is dietary shifts associated with increasing size. Iverson et al. (2002) showed age- and size-related differences in dietary indicator FAs in Pacific herring, namely C20 and C22 MUFAs, the saturate C14:0, EPA, and DHA. However, Okada \& Morrissey (2007) showed that differences in FA composition attributable to size classes were insignificant in Pacific sardines, especially in comparison to differences attributable to season. Nonetheless, differences in FA composition related to ontogenetic shifts can be meaningful factors for consideration, which may be addressed using other species under laboratory conditions.

Results of our study show interannual and seasonal differences in lipid and FA components between species. Each species was successful at indicating particular lipid components (Table 1), and each species could be distinguished from another by their lipid and FA 
composition (Table 2). One of the many physiological factors that may have contributed to interspecific differences in lipid and FA profiles is spawn timing. It has been shown that spawning Pacific herring become lipid depleted and n-3 PUFA concentrations are reduced to levels of a lean fish species (e.g. walleye pollock; Huynh et al. 2007). Total lipid content increased in northern anchovy and Pacific sardine from early to late summer during both years. However, total lipid content decreased from early to late summer in whitebait smelt and changed very little in Pacific herring during both years of sampling (Appendix 1c,d). Northern anchovy and Pacific sardine spawn off Oregon and Washington during late spring and early summer (Laroche \& Richardson 1980, Richardson 1981, Emmett et al. 2006). Pacific herring spawn off the Pacific Northwest in early spring (Ware 1985, Huynh et al. 2007). Presently, it is not known exactly where and when whitebait smelt spawn (Miller \& Lea 1972, Hart 1973), but the occurrence of whitebait smelt larvae in estuaries of the Pacific Northwest during fall (Misitano 1976, Bottom \& Jones 1990) suggests that they may be late summer spawners. The lack of change in Pacific herring lipids during summer was likely because fish sampled were of sizes and weights consistent with immature, non-spawning, 1 to $2 \mathrm{yr}$ old subadults (Fig. 2; Ware 1985, Tanasichuk 2002, Huynh et al. 2007).

Our results indicated that MUFA profiles, particularly in Pacific herring and whitebait smelt, were linked to zooplankton abundance in the northern California Current. ISA selected Pacific herring as the best indicator of C20:1n-9 and whitebait smelt as the best indicator of $\Sigma$ MUFA (Table 1). Pacific herring MUFAs constituted from 20.8 to $41.5 \%$ of total FAs (Appendix 1c), which was highly variable, but consistent with herring FA profiles reported elsewhere (Iverson et al. 2002, Huynh et al. 2007). Elevated levels of MUFAs, particularly C20:1n-9 and C22:1n-9, are effective tracers of copepod consumption in forage fish (Dalsgaard et al. 2003, Budge et al. 2006). They are the product of oxidized C20:1 and C22:1 fatty alcohols of wax esters, which are the primary constituent of coldwater copepods (Graeve et al. 1994) and are synthesized de novo. All 4 species of forage fish sampled in the present study consume zooplankton as part of their regular diet, but Pacific herring and whitebait smelt in the CCLME typically feed most heavily on calanoid copepods and larger zooplankton, such as euphausiids (Brodeur et al. 1987, Brodeur \& Pearcy 1992, Miller \& Brodeur 2007). In 2006, MUFA concentrations were larger in all species of forage fish, especially Pacific herring, than during 2005 (Appendix 1c). Low concentrations of MUFA biomarkers (particularly C20 and C22) in 2005 compared to 2006 supported previous observations of an anomalous, lipid-poor zooplankton community off Oregon and Washington during 2005 (Mackas et al. 2006). Reductions in both copepod biomass and their food quality, as evidenced by monitoring abundance and FA composition, were similarly recorded in the Strait of Georgia, off British Columbia, Canada, during 2005 (El-Sabaawi et al. 2009b).

PUFAs containing 18 carbons are considered to be FA markers of green algae or terrestrial debris (Budge \& Parrish 1998, Dalsgaard et al. 2003), and C18 PUFAs have also been used to reliably track flagellates in marine food webs (El-Sabaawi et al. 2009b). However, as a flagellate marker, C18 PUFAs did not show any significant trend with time, with the exceptions of LA and ALA significantly increasing in late summer 2006 compared to early summer 2005 in northern anchovy and GLA increasing significantly in Pacific sardine (Appendix 1), indicating that similar proportions of flagellates had been consumed in both years. Nevertheless, this result could suggest that northwest coastal and estuarine ecosystems can receive inputs of green algae from freshwater sources, possibly from the Columbia River in the present study.

In the absence of upwelling in early summer 2005, large pools of warm water accumulated on the shelf along the eastern boundary current region off Oregon and Washington, depressing the thermocline and thereby reducing the availability of nutrients (Barth et al. 2007, Goericke et al. 2007, Henson \& Thomas 2007). Under these conditions, dinoflagellates dominated phytoplankton biomass in a floral shift away from normal conditions wherein diatoms would dominate primary productivity in the California Current (Jester et al. 2009). We found that lipid-content values of forage fish were negatively related to weight mass percentages of DHA and positively related to those of EPA (Fig. 5). These results suggested that the mechanisms driving large diatom blooms may be related to the mechanisms influencing lipid and FA composition, although other researchers have found that diatom blooms alone may impede copepod reproduction (Jónasdóttir et al. 1998, Ianora et al. 2003). Clearly, the importance of diatom-based productivity on the lower food web remains poorly understood. Equally important is gaining better understanding of the nutritional value of dinoflagellate-based production.

By measuring whole lipids and FA in forage fish as they relate to climate variables, we can better predict ecosystem-level changes in coastal food webs and better inform management decisions to protect fishery resources. Interspecific differences in lipid and FA composition were expected based on physiology; however, interannual and seasonal differences (between 2005 and 2006 and between early and late summer) were consistent with our predictions based on oceano- 
graphic variability across sampling periods, namely variability in primary production (Table 2). Our samples were collected in association with other studies, which also aimed to better understand forage fish populations throughout the northern CCLME (Emmett et al. 2005, Litz et al. 2008). Although we were not able to sample many species across years and seasons, the present study was nonetheless a promising first step in evaluating forage fish lipids and FAs as biomarkers of ocean productivity and provided a start to classification of lipid content and FA composition of several dominant forage species in the northern CCLME. For further studies, we recommend evaluations of Pacific sardine total lipid content as a proxy for ocean conditions and of Pacific herring and whitebait smelt FA composition as a biomarker for copepod prey availability. Additional research into the effects of spawning on lipid and FA composition for these important forage fish is recommended, along with research examining the causative links between physical oceanography, diet, size, age class, and population dynamics, to provide further insight into this critical food source within the CCLME.

Acknowledgements. The authors gratefully acknowledge J. Peterson for providing sea-surface temperature and chl a concentration data collected along the Newport Hydrographic Line in 2005 and 2006. We are grateful to M. Morrisey, L. Copeman, R. Baldwin, J. Colbert, and especially to T. Okada for technical support and advice. This work would not have been possible without the assistance of a Mamie Markham Research Award, a grant from Oregon State University's Hatfield Marine Science Center. Comments on early drafts of this paper provided by T. O'Higgins, F. Prahl, R. ElSabaawi, E. Casillas, and 3 anonymous reviewers made for a stronger paper. Finally, thanks to the captain and crews of all the research vessels, who aided in the collection of fish used in the present study.

\section{LITERATURE CITED}

Anderson MJ (2001) A new method for non-parametric multivariate analysis of variance. Austral Ecol 26:32-46

Association of Official Analytical Chemists (AOAC) (1998) AOAC Official Method 991.39. Fatty acids in encapsulated fish oils and fish oil methyl and ethyl esters. In: Bueno MP (ed) Official methods of analysis of AOAC International, 16th edn. AOAC International, Arlington, VA

Barber RT, Chavez FP (1983) Biological consequences of El Niño. Science 222:1203-1210

Barth JA, Menge BA, Lubchenco J, Chan F and others (2007) Delayed upwelling alters nearshore coastal ocean ecosystems in the northern California Current. Proc Natl Acad Sci USA 104:3719-3724

> Bottom DL, Jones KK (1990) Species composition, distribution, and invertebrate prey of fish assemblages in the Columbia River estuary. Prog Oceanogr 25:243-270

Brodeur RD, Pearcy WG (1992) Effects of environmental vari- ability on trophic interactions and food web structure in a pelagic upwelling ecosystem. Mar Ecol Prog Ser 84: 101-119

Brodeur RD, Lorz HV, Pearcy WG (1987) Food habits and dietary variability of pelagic nekton off Oregon and Washington, 1979-1984. NOAA-TM-NMFS-57, US Department of Commerce, Seattle, WA

Brodeur RD, Fisher JP, Emmett RL, Morgan CA, Casillas E (2005) Species composition and community structure of pelagic nekton off Oregon and Washington under variable oceanographic conditions. Mar Ecol Prog Ser 298:41-57

> Brodeur RD, Ralston S, Emmett RL, Trudel M, Auth TD, Phillips AJ (2006) Anomalous pelagic nekton abundance, distribution, and apparent recruitment in the northern California Current in 2004 and 2005. Geophys Res Lett 33: L22S08 doi: 10.1029/2006GLO26614

Budge SM, Parrish CC (1998) Lipid biogeochemistry of plankton, settling matter and sediments in Trinity Bay, Newfoundland. II. FA. Org Geochem 29:1547-1559

Budge SM, Iverson SJ, Koopman HN (2006) Studying trophic ecology in marine ecosystems using fatty acids: a primer on analysis and interpretation. Mar Mamm Sci 22:759-801

Chavez FP, Ryan J, Lluch-Cota SE, Niquen CM (2003) From anchovies to sardines and back: multidecadal change in the Pacific Ocean. Science 299:217-221

Copeman LA, Parrish CC (2002) Lipid composition of malpigmented and normally pigmented newly settled yellowtail flounder, Limanda ferruginea (Storer). Aquac Res 33: 1209-1219

> Dalsgaard J, St. John MA, Kattner G, Müller-Navarra D, Hagen W (2003) Fatty acid trophic markers in the pelagic marine environment. Adv Mar Biol 46:225-340

Dufrêne M, Legendre P (1997) Species assemblages and indicator species: the need for a flexible asymmetrical approach. Ecol Monogr 61:53-73

El-Sabaawi R, Dower JF, Kainz M, Mazumder A (2009a) Characterizing dietary variability and trophic positions of coastal calanoid copepods: insight from stable isotopes and fatty acids. Mar Biol 156:225-235

El-Sabaawi R, Dower JF, Kainz M, Mazumder A (2009b) Interannual variability in fatty acid composition of the copepod Neocalanus plumchrus in the Strait of Georgia, British Columbia. Mar Ecol Prog Ser 382:151-161

Emmett RL, Brodeur RD, Miller TW, Pool SS, Krutzikowsky GK, Bentley PJ, McCrae J (2005) Pacific sardine (Sardinops sagax) abundance, distribution, and ecological relationships in the Pacific Northwest. Calif Coop Ocean Fish Invest Rep 46:122-143

Emmett RL, Krutzikowsky GK, Bentley PJ (2006) Abundance and distribution of pelagic piscivorous fishes in the Columbia River plume during spring/early summer 1998-2003: relationship to oceanographic conditions, forage fishes and juvenile salmonids. Prog Oceanogr 68:1-26

> Folch J, Lees M, Sloane-Stanley GH (1957) A simple method for the isolation and purification of total lipids from animal tissues. J Biol Chem 226:497-509

$>$ Francis RC, Hare SR (1994) Decadal-scale regime shifts in the large marine ecosystems of the North-East Pacific: a case for historical science. Fish Oceanogr 3:279-291

Fraser AJ, Sargent JR, Gamble JC, Seaton DD (1989) Formation and transfer of fatty acids in an enclosed marine food chain comprising phytoplankton, zooplankton, and herring (Clupea harengus L.) larvae. Mar Chem 27:1-18

> Fulton EA, Smith ADM, Punt AE (2005) Which ecological indicators can robustly detect effects of fishing? ICES J Mar Sci 62:540-551

Goericke R, Venrick E, Koslow T, Sydeman WJ and others 
(2007) The state of the California Current, 2006-2007: regional and local processes dominate. Calif Coop Ocean Fish Invest Rep 48:33-66

> Graeve M, Hagen W, Kattner G (1994) Herbivorous or omnivorous? On the significance of lipid compositions as trophic markers in Antarctic copepods. Deep Sea Res I 41: 915-924

Graeve M, Albers C, Kattner G (2005) Assimilation and biosynthesis of lipids in Arctic Calanus species based on feeding experiments with ${ }^{13} \mathrm{C}$ labelled diatom. J Exp Mar Biol Ecol 317:109-125

> Hare SR, Mantua NJ (2000) Empirical evidence for North Pacific regime shifts in 1977 and 1989. Prog Oceanogr 47: $103-145$

Hart JL (1973) Pacific fishes of Canada. Bull Fish Res Board Can 180:1-740

Henson SA, Thomas AC (2007) Interannual variability in timing of bloom initiation in the California Current System. J Geophys Res 112:C08007 doi: 10.29/2006JC003960

Herman DP, Burrows DG, Wade PR, Durban JW and others (2005) Feeding ecology of eastern North Pacific killer whales Orcinus orca from fatty acid, stable isotope and organochlorine analyses of blubber biopsies. Mar Ecol Prog Ser 302:275-291

Hooff RC, Peterson WT (2006) Copepod biodiversity as an indicator of changes in ocean and climate conditions of the northern California current ecosystem. Limnol Oceanogr 51:2607-2620

> Huynh MD, Kitts DD, Hu C, Trites AW (2007) Comparison of fatty acid profiles of spawning and non-spawning Pacific herring, Clupea pallasi. Comp Biochem Physiol B 146: $504-511$

Ianora A, Poulet SA, Miralto A (2003) The effect of diatoms on copepod reproduction: a review. Phycologia 42:351-363

Iverson SJ (2009) Tracing aquatic food webs using fatty acids: from qualitative indicators to quantitative determination. In: Arts MT, Brett MT, Kainz MJ (eds) Lipids in aquatic ecosystems. Springer, New York

> Iverson SJ, Frost KJ, Lowry LF (1997) Fatty acid signatures reveal fine scale structure of foraging distribution of harbor seals and their prey in Prince William Sound, Alaska. Mar Ecol Prog Ser 151:255-271

Iverson SJ, Frost KJ, Lang SLC (2002) Fat content and fatty acid composition of forage fish and invertebrates in Prince William Sound, Alaska: factors contributing to among and within species variability. Mar Ecol Prog Ser 241:161-181

Iverson SJ, Field C, Bowen WD, Blanchard W (2004) Quantitative fatty acid signature analysis: a new method of estimating predator diet. Ecol Monogr 74:211-235

Iverson SJ, Springer AM, Kitaysky AS (2007) Seabirds as indicators of food web structure and ecosystem variability: qualitative and quantitative diet analyses using fatty acids. Mar Ecol Prog Ser 352:235-244

> Jester R, Lefebvre K, Langlois G, Vigilant V, Baugh K, Silver MW (2009) A shift in the dominant toxin-producing algal species in central California alters phycotoxins in food webs. Harmful Algae 8:291-298

Jónasdóttir SH, Kiørboe T, Tang KW, St. John M, Visser AW, Saiz E, Dam HG (1998) Role of diatoms in copepod reproduction: good, harmless or toxic? Mar Ecol Prog Ser 172: 305-308

Kainz M, Arts MT, Mazumder A (2004) Essential FA in the planktonic food web and their ecological role for higher trophic levels. Limnol Oceanogr 49:1784-1793

Kovala PE, Larrance JP (1966) Computation of phytoplankton cell numbers, cell volume, cell surface area and plasma volume per litre, from microscopical counts. Special
Report 38, University of Washington, Seattle, WA

Krutzikowsky GK, Emmett RL (2005) Diel differences in surface trawl fish catches off Oregon and Washington. Fish Res 71:365-371

Laroche JL, Richardson SL (1980) Reproduction of northern anchovy, Engraulis mordax, off Oregon and Washington. Fish Bull (Wash DC) 78:603-618

Litz MNC, Emmett RL, Brodeur RD, Heppell SS (2008) Ecology of the northern subpopulation of northern anchovy (Engraulis mordax) off the U.S. West Coast. Calif Coop Ocean Fish Invest Rep 49:167-182

Litzow MA, Bailey KM, Prahl FG, Heinz R (2006) Climate regime shifts and reorganization of fish communities: the essential fatty acid limitation hypothesis. Mar Ecol Prog Ser 315:1-11

> Mackas DL, Peterson WT, Ohman MD, Lavaniegos BE (2006) Zooplankton anomalies in the California Current system before and during warm ocean conditions of 2005. Geophys Res Lett 33:L22S07 doi: 10.1029/2006GL027930

McCune B, Grace J (2002) Analysis of ecological communities. MjM Software Design, Gleneden Beach, OR

Miller TW, Brodeur RD (2007) Diets and trophic relationships among dominant marine nekton within the northern California Current ecosystem. Fish Bull (Wash DC) 105: 548-559

Miller DJ, Lea RN (1972) Guide to the coastal marine fishes of California. Fish Bull Calif Dept Fish 157:1-235

Misitano DA (1976) Species composition and relative abundance of larval and post-larval fishes in the Columbia River estuary. Fish Bull (Wash DC) 75:218-222

- Müller-Navarra DC, Brett MT, Liston AM, Goldman CR (2000) A highly unsaturated fatty acid predicts carbon transfer between primary producers and consumers. Nature 403:74-77

Okada T, Morrissey MT (2007) Seasonal changes in intrinsic characteristics of Pacific sardine (Sardinops sagax). J Aquat Food Prod Technol 16:51-71

Parrish CC (1999) Determination of total lipids, lipid classes and fatty acids in aquatic samples. In: Arts M, Wainmann BC (eds) Lipids in freshwater ecosystems. Springer, New York

Peterson WT, Keister JE (2003) Interannual variability in copepod community composition at a coastal station in the northern California Current: a multivariate approach. Deep Sea Res II 50:2499-2517

Peterson WT, Schwing FB (2003) A new climate regime in Northeast Pacific ecosystems. Geophys Res Lett 30:1896 doi: 10.1029/2003GL017528

Peterson WT, Emmett R, Goericke R, Venrick E and others (2006) The state of the California Current 2005-2006: warm in the north, cool in the south. Calif Coop Ocean Fish Invest Rep 47:30-74

Phillips AJ, Ralston S, Brodeur RD, Auth TD, Emmett RL, Johnson C, Wespestad VG (2007) Recent pre-recruit Pacific hake (Merluccius productus) occurrences in the northern California Current suggest a northward expansion of their spawning area. Calif Coop Ocean Fish Invest Rep 48:215-229

Pierce SD, Barth JA, Thomas RE, Fleischer GW (2006) Anomalously warm July 2005 in the northern California Current: historical context and the significance of cumulative wind stress. Geophys Res Lett 33:L22S04 doi: 10.1029/ 2006GL027149

Richardson SL (1981) Spawning biomass and early life of northern anchovy, Engraulis mordax, in the northern subpopulation off Oregon and Washington. Fish Bull (Wash DC) 78:855-876 
Sargent JR, Parkes RJ, Mueller-Harvey I, Henderson RJ (1987) Lipid biomarkers in marine ecology. In: Sleigh MA (ed) Microbes in the sea. Wiley and Sons, New York

Schwing FB, Bond NA, Bograd SJ, Mitchell T, Alexander MA, Mantua NJ (2006) Delayed coastal upwelling along the U.S. West Coast in 2005: a historical perspective. Geophys Res Lett 33:L22S01 doi: 10.1029/2006GL026911

St. John MA, Clemmesen C, Lund T, Köster T (2001) Diatom production in the marine environment: implications for larval fish growth and condition. ICES J Mar Sci 58:1106-1113

Sydeman WJ, Bradley RW, Warzybok P, Abraham CL and others (2006) Planktivorous auklet Ptychoramphus aleuticus responses to ocean climate, 2005: unusual atmospheric blocking? Geophys Res Lett 33:L22S09 doi: 10.1029/ 2006GL026736

Tanasichuk RW (2002) Implications of interannual variability in euphausiid population biology for fish production along the south-west coast of Vancouver Island: a synthesis. Fish Oceanogr 11:18-30
Thompson PA, Guo M, Harrison PJ, Whyte JNC (1992) Effects of variations in temperature. II. On the fatty acid composition of eight marine phytoplankton. J Phycol 28:488-497

Tocher DR (2003) Metabolism and functions of lipids and FA in teleost fish. Rev Fish Sci 11:107-184

Trites AW, Miller AJ, Maschner HDG, Alexander MA and others (2007) Bottom-up forcing and the decline of Steller sea lions (Eumetopias jubatas) in Alaska: assessing the ocean climate hypothesis. Fish Oceanogr 16:46-67

von Utermöhl H (1931) Neue Wege in der quantitativen Erfahrung des Planktons (mit besonderer Berücksichtigung des Ultraplanktons). Verh Int Ver Theor Angew Limnol 5:567-595

$>$ Wang SW, Iverson SJ, Springer AM, Hatch SA (2009) Spatial and temporal diet segregation in northern fulmars Fulmarus glacialis breeding in Alaska: insights from fatty acid signatures. Mar Ecol Prog Ser 377:299-307

Ware DM (1985) Life history characteristics, reproductive value, and resilience of Pacific herring (Clupea pallasi). Can J Fish Aquat Sci 42(Suppl 1):s127-s137

Appendix 1. Engraulis mordax, Sardinops sagax, Clupea pallasi and Allosmerus elongatus. Fatty acid (FA, \% total FA) and lipid (\% wet weight) values (mean \pm SD) of (a) northern anchovy, (b) Pacific sardine, (c) Pacific herring, and (d) whitebait smelt sampled during early and late summer, 2005 and 2006. Values for each compound that do not share a common superscript are significantly different (1-way ANOVA, Tukey's honestly significant difference, $\mathrm{p}<0.05)$. SFA: saturated fatty acid; MUFA: monounsaturated FA; PUFA: polyunsaturated FA; n-3 PUFA: PUFA containing a final carbon-carbon double bond in the n-3 position; LA: linoleic acid; GLA: $\gamma$-linolenic acid; ALA: $\alpha$-linolenic acid; ARA: arachidonic acid; EPA: eicosapentaeonic acid; DHA: docosahexaeonic acid

\begin{tabular}{|c|c|c|c|c|}
\hline \multirow{2}{*}{ Components } & \multicolumn{2}{|c|}{$2005 \longleftarrow$} & \multicolumn{2}{|c|}{2006} \\
\hline & Early summer & Late summer & Early summer & Late summer \\
\hline \multicolumn{5}{|c|}{ (a) Northern anchovy } \\
\hline C14:0 & $4.51 \pm 0.79^{\mathrm{a}}$ & $8.52 \pm 0.46^{\mathrm{bc}}$ & $9.00 \pm 0.43^{b}$ & $7.55 \pm 0.90^{\mathrm{c}}$ \\
\hline C15:0 & $0.42 \pm 0.11^{\mathrm{a}}$ & $0.47 \pm 0.11^{\mathrm{a}}$ & $0.58 \pm 0.23^{\mathrm{a}}$ & $0.51 \pm 0.19^{\mathrm{a}}$ \\
\hline C16:0 & $29.27 \pm 2.94^{\mathrm{a}}$ & $25.84 \pm 0.35^{b}$ & $22.28 \pm 0.54^{\mathrm{c}}$ & $27.24 \pm 1.23^{\mathrm{ab}}$ \\
\hline $\mathrm{C} 17: 0$ & $0.15 \pm 0.04^{\mathrm{a}}$ & $1.44 \pm 0.08^{\mathrm{b}}$ & $1.25 \pm 0.39^{\mathrm{b}}$ & $0.70 \pm 0.14^{\mathrm{c}}$ \\
\hline C18:0 & $6.23 \pm 0.77^{a}$ & $6.38 \pm 0.82^{a}$ & $4.79 \pm 0.57^{b}$ & $5.74 \pm 1.24^{\mathrm{ab}}$ \\
\hline C20:0 & $0.05 \pm 0.08^{\mathrm{a}}$ & $0.02 \pm 0.00^{\mathrm{a}}$ & $0.05 \pm 0.04^{a}$ & $0.05 \pm 0.06^{\mathrm{a}}$ \\
\hline $\mathrm{C} 23: 0$ & $0.29 \pm 0.04^{\mathrm{a}}$ & $0.10 \pm 0.00^{\mathrm{b}}$ & $0.14 \pm 0.03^{\mathrm{c}}$ & $0.17 \pm 0.02^{\mathrm{c}}$ \\
\hline$\Sigma \mathrm{SFA}$ & $40.92 \pm 2.88^{\mathrm{ab}}$ & $42.77 \pm 0.45^{\mathrm{a}}$ & $38.09 \pm 0.87^{b}$ & $41.98 \pm 1.26^{\mathrm{a}}$ \\
\hline C14:1n-5 & $0.00 \pm 0.00^{\mathrm{a}}$ & $0.04 \pm 0.00^{\mathrm{bc}}$ & $0.03 \pm 0.04^{\mathrm{ab}}$ & $0.07 \pm 0.03^{\mathrm{c}}$ \\
\hline C16:1n-7 & $5.27 \pm 0.33^{a}$ & $9.82 \pm 0.67^{\mathrm{b}}$ & $9.99 \pm 0.67^{\mathrm{b}}$ & $6.98 \pm 0.58^{\mathrm{c}}$ \\
\hline C17:1n-9 & $0.78 \pm 0.26^{\mathrm{a}}$ & $1.79 \pm 0.26^{\mathrm{b}}$ & $1.52 \pm 0.65^{\mathrm{bc}}$ & $1.03 \pm 0.30^{\mathrm{ac}}$ \\
\hline C18:1n-9 & $7.11 \pm 0.70^{\mathrm{a}}$ & $7.75 \pm 0.33^{\mathrm{a}}$ & $6.13 \pm 0.34^{\mathrm{b}}$ & $7.80 \pm 0.66^{\mathrm{a}}$ \\
\hline C20:1n-9 & $1.37 \pm 0.27^{\mathrm{a}}$ & $1.33 \pm 0.13^{\mathrm{a}}$ & $2.44 \pm 0.88^{\mathrm{b}}$ & $2.63 \pm 0.32^{\mathrm{b}}$ \\
\hline C22:1n-9 & $0.94 \pm 0.24^{\mathrm{a}}$ & $0.90 \pm 0.11^{\mathrm{a}}$ & $1.90 \pm 0.91^{\mathrm{b}}$ & $1.54 \pm 0.25^{\mathrm{ab}}$ \\
\hline $\mathrm{C} 24: 1 \mathrm{n}-9$ & $1.05 \pm 0.59^{\mathrm{a}}$ & $0.21 \pm 0.03^{\mathrm{b}}$ & $0.19 \pm 0.03^{\mathrm{b}}$ & $0.40 \pm 0.08^{\mathrm{b}}$ \\
\hline$\Sigma$ MUFA & $16.51 \pm 0.64^{\mathrm{a}}$ & $21.85 \pm 0.86^{b}$ & $22.19 \pm 0.34^{b}$ & $20.45 \pm 0.95^{\mathrm{c}}$ \\
\hline C18:2n-6 (LA) & $1.75 \pm 0.23^{\mathrm{a}}$ & $1.73 \pm 0.05^{\mathrm{a}}$ & $1.74 \pm 0.45^{\mathrm{a}}$ & $2.47 \pm 0.15^{\mathrm{b}}$ \\
\hline C18:3n-6 (GLA) & $0.13 \pm 0.23^{a}$ & $0.42 \pm 0.11^{\mathrm{b}}$ & $0.48 \pm 0.12^{\mathrm{b}}$ & $0.28 \pm 0.07^{\mathrm{ab}}$ \\
\hline C18:3n-3 (ALA) & $0.53 \pm 0.19^{\mathrm{a}}$ & $0.61 \pm 0.03^{\mathrm{a}}$ & $0.81 \pm 0.30^{a}$ & $1.29 \pm 0.14^{\mathrm{b}}$ \\
\hline C20:2n-6 & $0.06 \pm 0.10^{\mathrm{a}}$ & $0.05 \pm 0.04^{\mathrm{a}}$ & $0.31 \pm 0.17^{\mathrm{b}}$ & $0.11 \pm 0.09^{\mathrm{a}}$ \\
\hline$C 20: 3 n-6$ & $0.05 \pm 0.08^{\mathrm{a}}$ & $0.01 \pm 0.02^{\mathrm{a}}$ & $0.08 \pm 0.10^{\mathrm{a}}$ & $0.13 \pm 0.11^{\mathrm{a}}$ \\
\hline$C 20: 3 n-3$ & $0.00 \pm 0.00^{\mathrm{a}}$ & $0.00 \pm 0.00^{\mathrm{a}}$ & $0.02 \pm 0.04^{\mathrm{a}}$ & $0.08 \pm 0.05^{b}$ \\
\hline C20:4n-6 (ARA) & $0.34 \pm 0.03^{\mathrm{a}}$ & $0.38 \pm 0.19^{a}$ & $0.51 \pm 0.12^{\mathrm{ab}}$ & $0.64 \pm 0.03^{\mathrm{b}}$ \\
\hline C20:5n-3 (EPA) & $9.99 \pm 1.02^{\mathrm{a}}$ & $19.37 \pm 0.61^{b}$ & $20.06 \pm 2.19^{b}$ & $14.65 \pm 0.58^{\mathrm{c}}$ \\
\hline $\mathrm{C} 22: 2 \mathrm{n}-6$ & $0.17 \pm 0.03^{\mathrm{a}}$ & $0.59 \pm 0.02^{\mathrm{b}}$ & $0.63 \pm 0.10^{\mathrm{b}}$ & $0.48 \pm 0.02^{\mathrm{c}}$ \\
\hline$C 22: 5 n-3$ & $2.16 \pm 0.36^{\mathrm{a}}$ & $2.24 \pm 0.26^{\mathrm{a}}$ & $3.79 \pm 0.69^{b}$ & $1.94 \pm 0.18^{a}$ \\
\hline C22:6n-3 (DHA) & $27.39 \pm 2.24^{\mathrm{a}}$ & $9.99 \pm 0.13^{\mathrm{b}}$ & $11.28 \pm 2.02^{\mathrm{b}}$ & $15.49 \pm 1.27^{\mathrm{c}}$ \\
\hline DHA/EPA & $2.76 \pm 0.27^{a}$ & $0.52 \pm 0.02^{\mathrm{b}}$ & $0.58 \pm 0.17^{\mathrm{b}}$ & $1.06 \pm 0.05^{\mathrm{c}}$ \\
\hline$\Sigma$ PUFA & $42.57 \pm 3.57^{\mathrm{a}}$ & $25.38 \pm 0.82^{\mathrm{b}}$ & $39.72 \pm 0.78^{\mathrm{ac}}$ & $37.57 \pm 1.98^{\mathrm{bc}}$ \\
\hline इn-3 PUFA & $40.06 \pm 3.34^{\mathrm{a}}$ & $32.21 \pm 0.86^{b}$ & $35.97 \pm 0.92^{\mathrm{c}}$ & $33.45 \pm 1.87^{\mathrm{bc}}$ \\
\hline Lipid & $0.92 \pm 0.56^{\mathrm{a}}$ & $9.73 \pm 2.34^{\mathrm{b}}$ & $4.91 \pm 1.56^{\mathrm{c}}$ & $5.68 \pm 2.54^{\mathrm{c}}$ \\
\hline
\end{tabular}


Appendix 1 (continued)

\begin{tabular}{|c|c|c|c|c|}
\hline \multirow[t]{2}{*}{ Components } & \multicolumn{2}{|c|}{2005} & \multicolumn{2}{|c|}{2006} \\
\hline & Early summer & Late summer & Early summer & Late summer \\
\hline \multicolumn{5}{|l|}{ (b) Pacific sardine } \\
\hline C14:0 & $9.19 \pm 0.85^{\mathrm{a}}$ & $9.15 \pm 0.91^{\mathrm{a}}$ & $8.61 \pm 2.35^{\mathrm{a}}$ & $7.32 \pm 0.56^{\mathrm{a}}$ \\
\hline C15:0 & $0.49 \pm 0.16^{\mathrm{a}}$ & $0.33 \pm 0.14^{\mathrm{a}}$ & $0.52 \pm 0.12^{\mathrm{a}}$ & $0.54 \pm 0.15^{\mathrm{a}}$ \\
\hline C16:0 & $24.37 \pm 1.70^{\mathrm{a}}$ & $25.56 \pm 0.86^{\mathrm{a}}$ & $24.68 \pm 1.10^{\mathrm{a}}$ & $24.78 \pm 1.33^{\mathrm{a}}$ \\
\hline $\mathrm{C} 17: 0$ & $1.17 \pm 0.26^{\mathrm{ab}}$ & $1.42 \pm 0.14^{\mathrm{a}}$ & $1.01 \pm 0.29^{\mathrm{b}}$ & $1.21 \pm 0.27^{\mathrm{ab}}$ \\
\hline C18:0 & $4.52 \pm 0.65^{\mathrm{a}}$ & $6.61 \pm 1.54^{\mathrm{a}}$ & $6.27 \pm 2.15^{\mathrm{a}}$ & $6.10 \pm 0.94^{a}$ \\
\hline $\mathrm{C} 20: 0$ & $0.03 \pm 0.01^{\mathrm{a}}$ & $0.03 \pm 0.00^{\mathrm{ab}}$ & $0.07 \pm 0.07^{\mathrm{ab}}$ & $0.09 \pm 0.02^{b}$ \\
\hline $\mathrm{C} 23: 0$ & $0.12 \pm 0.02^{\mathrm{a}}$ & $0.09 \pm 0.01^{\mathrm{a}}$ & $0.19 \pm 0.04^{\mathrm{b}}$ & $0.14 \pm 0.04^{\mathrm{a}}$ \\
\hline$\Sigma$ SFA & $39.89 \pm 1.54^{\mathrm{a}}$ & $43.19 \pm 1.55^{\mathrm{b}}$ & $41.35 \pm 1.78^{\mathrm{ab}}$ & $40.16 \pm 1.72^{\mathrm{a}}$ \\
\hline C14:1n-5 & $0.01 \pm 0.02^{\mathrm{a}}$ & $0.01 \pm 0.02^{\mathrm{a}}$ & $0.04 \pm 0.03^{\mathrm{a}}$ & $0.04 \pm 0.00^{\mathrm{a}}$ \\
\hline C16:1n-7 & $11.62 \pm 1.03^{a}$ & $10.32 \pm 1.01^{\mathrm{ac}}$ & $5.52 \pm 2.11^{\mathrm{b}}$ & $8.23 \pm 0.98^{c}$ \\
\hline $\mathrm{C} 17: 1 \mathrm{n}-9$ & $1.37 \pm 0.34^{\mathrm{a}}$ & $1.74 \pm 0.36^{\mathrm{a}}$ & $1.50 \pm 0.68^{\mathrm{a}}$ & $2.00 \pm 0.35^{\mathrm{a}}$ \\
\hline C18:1n-9 & $6.14 \pm 0.63^{\mathrm{a}}$ & $7.77 \pm 0.65^{\mathrm{b}}$ & $6.77 \pm 1.14^{\mathrm{ab}}$ & $6.55 \pm 1.01^{\mathrm{ab}}$ \\
\hline $\mathrm{C} 20: 1 \mathrm{n}-9$ & $0.90 \pm 0.33^{a}$ & $1.20 \pm 0.44^{\mathrm{c}}$ & $2.69 \pm 0.81^{\mathrm{b}}$ & $2.13 \pm 0.66^{\mathrm{bc}}$ \\
\hline $\mathrm{C} 22: 1 \mathrm{n}-9$ & $0.32 \pm 0.33^{\mathrm{a}}$ & $0.34 \pm 0.21^{\mathrm{a}}$ & $1.78 \pm 0.78^{b}$ & $1.26 \pm 0.94^{\mathrm{ab}}$ \\
\hline $\mathrm{C} 24: 1 \mathrm{n}-9$ & $0.43 \pm 0.12^{\mathrm{a}}$ & $0.48 \pm 0.12^{\mathrm{a}}$ & $0.40 \pm 0.12^{\mathrm{a}}$ & $0.40 \pm 0.10^{\mathrm{a}}$ \\
\hline$\Sigma$ MUFA & $20.79 \pm 1.10^{\mathrm{ab}}$ & $21.86 \pm 1.39^{a}$ & $18.70 \pm 1.86^{\mathrm{b}}$ & $20.62 \pm 0.64^{\mathrm{ab}}$ \\
\hline C18:2n-6 (LA) & $1.60 \pm 0.33^{\mathrm{a}}$ & $1.53 \pm 0.11^{\mathrm{a}}$ & $2.26 \pm 0.94^{\mathrm{a}}$ & $2.02 \pm 0.35^{\mathrm{a}}$ \\
\hline C18:3n-6 (GLA) & $0.39 \pm 0.03^{\mathrm{a}}$ & $0.50 \pm 0.03^{\mathrm{b}}$ & $0.41 \pm 0.10^{\mathrm{ab}}$ & $0.62 \pm 0.05^{\mathrm{c}}$ \\
\hline C18:3n-3 (ALA) & $0.78 \pm 0.31^{\mathrm{ab}}$ & $0.52 \pm 0.06^{\mathrm{a}}$ & $0.81 \pm 0.32^{\mathrm{ab}}$ & $0.99 \pm 0.22^{\mathrm{b}}$ \\
\hline $\mathrm{C} 20: 2 \mathrm{n}-6$ & $0.42 \pm 0.32^{\mathrm{ab}}$ & $0.66 \pm 0.11^{\mathrm{a}}$ & $0.35 \pm 0.22^{\mathrm{ab}}$ & $0.29 \pm 0.16^{\mathrm{b}}$ \\
\hline$C 20: 3 n-6$ & $0.24 \pm 0.20^{\mathrm{a}}$ & $0.13 \pm 0.04^{\mathrm{a}}$ & $0.16 \pm 0.14^{\mathrm{a}}$ & $0.14 \pm 0.02^{\mathrm{a}}$ \\
\hline$C 20: 3 n-3$ & $0.21 \pm 0.14^{\mathrm{a}}$ & $0.00 \pm 0.00^{\mathrm{b}}$ & $0.05 \pm 0.05^{\mathrm{b}}$ & $0.04 \pm 0.04^{\mathrm{b}}$ \\
\hline C20:4n-6 (ARA) & $1.17 \pm 0.19^{a}$ & $0.36 \pm 0.40^{\mathrm{b}}$ & $0.56 \pm 0.42^{\mathrm{b}}$ & $1.18 \pm 0.25^{a}$ \\
\hline C20:5n-3 (EPA) & $20.88 \pm 2.72^{\mathrm{a}}$ & $19.14 \pm 2.13^{a}$ & $18.04 \pm 1.22^{\mathrm{a}}$ & $18.80 \pm 0.90^{\mathrm{a}}$ \\
\hline $\mathrm{C} 22: 2 \mathrm{n}-6$ & $0.61 \pm 0.05^{\mathrm{a}}$ & $0.65 \pm 0.03^{\mathrm{a}}$ & $0.62 \pm 0.08^{a}$ & $0.77 \pm 0.02^{\mathrm{b}}$ \\
\hline $\mathrm{C} 22: 5 \mathrm{n}-3$ & $3.29 \pm 0.08^{\mathrm{a}}$ & $3.54 \pm 0.15^{\mathrm{ab}}$ & $3.43 \pm 0.46^{\mathrm{ab}}$ & $3.77 \pm 0.16^{\mathrm{b}}$ \\
\hline C22:6n-3 (DHA) & $9.72 \pm 1.78^{\mathrm{ac}}$ & $7.92 \pm 1.35^{\mathrm{a}}$ & $13.25 \pm 1.61^{\mathrm{b}}$ & $10.59 \pm 1.75^{\mathrm{c}}$ \\
\hline DHA/EPA & $0.48 \pm 0.13^{\mathrm{a}}$ & $0.42 \pm 0.09^{a}$ & $0.74 \pm 0.11^{\mathrm{b}}$ & $0.57 \pm 0.11^{\mathrm{ab}}$ \\
\hline$\Sigma$ PUFA & $39.32 \pm 1.72^{\mathrm{a}}$ & $34.95 \pm 2.26^{\mathrm{b}}$ & $39.95 \pm 1.47^{\mathrm{a}}$ & $39.22 \pm 1.99^{\mathrm{a}}$ \\
\hline 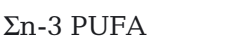 & $34.88 \pm 1.69^{a}$ & $31.11 \pm 2.57^{\mathrm{b}}$ & $35.58 \pm 1.62^{\mathrm{a}}$ & $34.19 \pm 1.66^{\mathrm{ab}}$ \\
\hline Lipid & $8.17 \pm 2.55^{\mathrm{a}}$ & $17.24 \pm 3.92^{\mathrm{b}}$ & $20.38 \pm 4.49^{b}$ & $19.27 \pm 1.92^{\mathrm{b}}$ \\
\hline \multicolumn{5}{|l|}{ (c) Pacific herring } \\
\hline $\mathrm{C} 14: 0$ & $4.27 \pm 0.64^{\mathrm{a}}$ & $4.87 \pm 0.24^{\mathrm{a}}$ & $7.99 \pm 1.44^{\mathrm{b}}$ & $5.30 \pm 0.53^{\mathrm{a}}$ \\
\hline C15:0 & $0.37 \pm 0.11^{\mathrm{a}}$ & $0.26 \pm 0.03^{\mathrm{a}}$ & $0.25 \pm 0.10^{\mathrm{a}}$ & $0.26 \pm 0.08^{\mathrm{a}}$ \\
\hline C16:0 & $24.28 \pm 1.54^{\mathrm{a}}$ & $24.30 \pm 1.40^{\mathrm{a}}$ & $19.55 \pm 1.51^{\mathrm{b}}$ & $21.89 \pm 0.39^{c}$ \\
\hline $\mathrm{C} 17: 0$ & $0.28 \pm 0.10^{\mathrm{a}}$ & $0.44 \pm 0.10^{\mathrm{a}}$ & $0.91 \pm 0.18^{\mathrm{b}}$ & $0.93 \pm 0.15^{\mathrm{b}}$ \\
\hline C18:0 & $4.06 \pm 0.39^{a}$ & $4.00 \pm 0.68^{a}$ & $4.22 \pm 1.10^{\mathrm{a}}$ & $9.40 \pm 1.48^{\mathrm{b}}$ \\
\hline C20:0 & $0.00 \pm 0.00^{\mathrm{a}}$ & $0.04 \pm 0.06^{\mathrm{a}}$ & $0.04 \pm 0.02^{\mathrm{a}}$ & $0.03 \pm 0.02^{\mathrm{a}}$ \\
\hline $\mathrm{C} 23: 0$ & $0.15 \pm 0.08^{a}$ & $0.14 \pm 0.01^{\mathrm{a}}$ & $0.05 \pm 0.04^{\mathrm{b}}$ & $0.10 \pm 0.00^{\mathrm{ab}}$ \\
\hline$\Sigma \mathrm{SFA}$ & $33.41 \pm 1.83^{a}$ & $34.04 \pm 1.33^{a}$ & $33.02 \pm 1.41^{\mathrm{a}}$ & $37.91 \pm 1.24^{\mathrm{b}}$ \\
\hline $\mathrm{C} 14: 1 \mathrm{n}-5$ & $0.04 \pm 0.10^{\mathrm{a}}$ & $0.00 \pm 0.00^{\mathrm{a}}$ & $0.03 \pm 0.02^{\mathrm{a}}$ & $0.01 \pm 0.02^{\mathrm{a}}$ \\
\hline$C 16: 1 n-7$ & $6.74 \pm 1.21^{\mathrm{a}}$ & $8.39 \pm 0.96^{b}$ & $7.85 \pm 0.94^{\mathrm{ab}}$ & $7.75 \pm 0.60^{\mathrm{ab}}$ \\
\hline $\mathrm{C} 17: 1 \mathrm{n}-9$ & $0.45 \pm 0.12^{\mathrm{a}}$ & $0.55 \pm 0.08^{a}$ & $1.16 \pm 0.11^{\mathrm{b}}$ & $1.56 \pm 0.40^{\mathrm{c}}$ \\
\hline C18:1n-9 & $5.84 \pm 1.11^{\mathrm{a}}$ & $10.19 \pm 1.08^{\mathrm{b}}$ & $8.11 \pm 1.12^{\mathrm{c}}$ & $11.17 \pm 0.85^{\mathrm{b}}$ \\
\hline $\mathrm{C} 20: 1 \mathrm{n}-9$ & $3.05 \pm 1.96^{\mathrm{a}}$ & $3.76 \pm 1.54^{\mathrm{a}}$ & $11.03 \pm 0.74^{\mathrm{b}}$ & $7.35 \pm 0.98^{\mathrm{c}}$ \\
\hline $\mathrm{C} 22: 1 \mathrm{n}-9$ & $3.72 \pm 1.87^{\mathrm{a}}$ & $4.46 \pm 1.90^{\mathrm{a}}$ & $12.91 \pm 1.49^{b}$ & $8.13 \pm 1.32^{\mathrm{c}}$ \\
\hline $\mathrm{C} 24: 1 \mathrm{n}-9$ & $0.93 \pm 0.48^{\mathrm{a}}$ & $0.84 \pm 0.21^{\mathrm{a}}$ & $0.44 \pm 0.22^{\mathrm{a}}$ & $0.80 \pm 0.19^{\mathrm{a}}$ \\
\hline$\Sigma$ MUFA & $20.76 \pm 3.96^{\mathrm{a}}$ & $28.19 \pm 3.37^{\mathrm{b}}$ & $41.54 \pm 1.20^{\mathrm{c}}$ & $36.78 \pm 2.74^{\mathrm{c}}$ \\
\hline C18:2n-6 (LA) & $1.23 \pm 0.13^{\mathrm{a}}$ & $1.29 \pm 0.28^{\mathrm{a}}$ & $1.26 \pm 0.23^{\mathrm{a}}$ & $1.42 \pm 0.11^{\mathrm{a}}$ \\
\hline C18:3n-6 (GLA) & $0.00 \pm 0.00^{\mathrm{a}}$ & $0.39 \pm 0.37^{\mathrm{b}}$ & $0.15 \pm 0.08^{\mathrm{ab}}$ & $0.24 \pm 0.04^{\mathrm{ab}}$ \\
\hline C18:3n-3 (ALA) & $0.48 \pm 0.09^{a}$ & $0.54 \pm 0.19^{\mathrm{ab}}$ & $0.70 \pm 0.11^{b}$ & $0.54 \pm 0.03^{\mathrm{ab}}$ \\
\hline C20:2n-6 & $0.08 \pm 0.12^{\mathrm{a}}$ & $0.14 \pm 0.12^{\mathrm{a}}$ & $0.14 \pm 0.03^{\mathrm{a}}$ & $0.15 \pm 0.11^{\mathrm{a}}$ \\
\hline C20:3n-6 & $0.00 \pm 0.00^{\mathrm{a}}$ & $0.08 \pm 0.06^{b}$ & $0.04 \pm 0.05^{\mathrm{ab}}$ & $0.09 \pm 0.02^{b}$ \\
\hline C20:3n-3 & $0.00 \pm 0.00^{\mathrm{a}}$ & $0.00 \pm 0.00^{\mathrm{a}}$ & $0.05 \pm 0.01^{\mathrm{a}}$ & $0.08 \pm 0.19^{\mathrm{a}}$ \\
\hline C20:4n-6 (ARA) & $0.30 \pm 0.06^{\mathrm{a}}$ & $0.38 \pm 0.02^{\mathrm{ab}}$ & $0.45 \pm 0.03^{\mathrm{b}}$ & $0.28 \pm 0.12^{\mathrm{a}}$ \\
\hline C20:5n-3 (EPA) & $11.71 \pm 0.52^{\mathrm{ab}}$ & $12.31 \pm 0.94^{\mathrm{a}}$ & $11.34 \pm 0.74^{\mathrm{ab}}$ & $10.55 \pm 0.92^{\mathrm{b}}$ \\
\hline C22:2n-6 & $0.17 \pm 0.08^{\mathrm{a}}$ & $0.25 \pm 0.03^{\mathrm{b}}$ & $0.38 \pm 0.03^{\mathrm{c}}$ & $0.35 \pm 0.02^{\mathrm{c}}$ \\
\hline
\end{tabular}


Appendix 1 (continued)

\begin{tabular}{|c|c|c|c|c|}
\hline \multirow{2}{*}{ Components } & \multicolumn{2}{|c|}{2005} & \multicolumn{2}{|c|}{2006} \\
\hline & Early summer & Late summer & Early summer & Late summer \\
\hline \multicolumn{5}{|l|}{$\Sigma$ MUFA (continued) } \\
\hline$C 22: 5 n-3$ & $1.27 \pm 0.21^{\mathrm{a}}$ & $1.34 \pm 0.05^{\mathrm{a}}$ & $1.42 \pm 0.16^{\mathrm{a}}$ & $1.40 \pm 0.10^{\mathrm{a}}$ \\
\hline C22:6n-3 (DHA) & $30.60 \pm 3.32^{\mathrm{a}}$ & $21.05 \pm 1.69^{b}$ & $9.50 \pm 0.87^{c}$ & $10.21 \pm 1.20^{\mathrm{c}}$ \\
\hline DHA/EPA & $2.62 \pm 0.34^{\mathrm{a}}$ & $1.71 \pm 0.06^{\mathrm{b}}$ & $0.84 \pm 0.07^{\mathrm{c}}$ & $0.97 \pm 0.04^{\mathrm{c}}$ \\
\hline$\Sigma$ PUFA & $45.83 \pm 3.11^{\mathrm{a}}$ & $37.78 \pm 2.64^{\mathrm{b}}$ & $25.45 \pm 1.66^{c}$ & $25.31 \pm 2.33^{\mathrm{c}}$ \\
\hline In-3 PUFA & $44.06 \pm 3.14^{\mathrm{a}}$ & $35.24 \pm 2.52^{\mathrm{b}}$ & $23.01 \pm 1.54^{\mathrm{c}}$ & $22.78 \pm 2.09^{c}$ \\
\hline Lipid & $3.13 \pm 2.59^{a}$ & $3.38 \pm 1.47^{a}$ & $7.59 \pm 4.64^{\mathrm{b}}$ & $5.65 \pm 3.47^{\mathrm{ab}}$ \\
\hline \multicolumn{5}{|l|}{ (d) Whitebait smelt } \\
\hline C14:0 & $5.77 \pm 0.41^{\mathrm{ac}}$ & $5.27 \pm 0.66^{\mathrm{a}}$ & $6.38 \pm 0.61^{\mathrm{bc}}$ & $7.32 \pm 0.82^{\mathrm{b}}$ \\
\hline C15:0 & $0.29 \pm 0.06^{\mathrm{a}}$ & $0.10 \pm 0.11^{\mathrm{b}}$ & $0.21 \pm 0.05^{\mathrm{ab}}$ & $0.19 \pm 0.01^{\mathrm{ab}}$ \\
\hline C16:0 & $21.52 \pm 0.50^{\mathrm{a}}$ & $22.10 \pm 1.15^{\mathrm{a}}$ & $20.00 \pm 0.61^{b}$ & $20.95 \pm 1.09^{\mathrm{ab}}$ \\
\hline C17:0 & $0.62 \pm 0.05^{\mathrm{a}}$ & $0.47 \pm 0.15^{\mathrm{a}}$ & $0.95 \pm 0.24^{\mathrm{b}}$ & $0.96 \pm 0.17^{b}$ \\
\hline C18:0 & $6.00 \pm 0.88^{a}$ & $5.87 \pm 2.44^{\mathrm{a}}$ & $14.01 \pm 1.95^{\mathrm{b}}$ & $9.17 \pm 1.56^{\mathrm{c}}$ \\
\hline $\mathrm{C} 20: 0$ & $0.02 \pm 0.02^{\mathrm{a}}$ & $0.03 \pm 0.06^{\mathrm{a}}$ & $0.02 \pm 0.00^{\mathrm{a}}$ & $0.02 \pm 0.01^{\mathrm{a}}$ \\
\hline C23:0 & $0.14 \pm 0.01^{\mathrm{a}}$ & $0.13 \pm 0.03^{\mathrm{ab}}$ & $0.10 \pm 0.00^{\mathrm{b}}$ & $0.07 \pm 0.04^{\mathrm{c}}$ \\
\hline$\Sigma$ SFA & $34.37 \pm 1.09^{a}$ & $33.97 \pm 3.04^{\mathrm{a}}$ & $41.67 \pm 1.79^{b}$ & $38.67 \pm 1.45^{\mathrm{b}}$ \\
\hline C14:1n-5 & $0.06 \pm 0.08^{\mathrm{a}}$ & $0.00 \pm 0.00^{\mathrm{a}}$ & $0.02 \pm 0.02^{\mathrm{a}}$ & $0.03 \pm 0.03^{\mathrm{a}}$ \\
\hline C16:1n-7 & $11.06 \pm 0.46^{\mathrm{a}}$ & $8.57 \pm 0.64^{b}$ & $10.18 \pm 0.70^{\mathrm{a}}$ & $11.15 \pm 0.74^{\mathrm{a}}$ \\
\hline C17:1n-9 & $0.82 \pm 0.28^{\mathrm{ab}}$ & $0.55 \pm 0.19^{\mathrm{b}}$ & $0.95 \pm 0.23^{\mathrm{a}}$ & $1.05 \pm 0.23^{\mathrm{a}}$ \\
\hline C18:1n-9 & $13.49 \pm 0.57^{a}$ & $17.02 \pm 3.99^{\mathrm{ab}}$ & $16.57 \pm 1.64^{\mathrm{ab}}$ & $18.19 \pm 1.54^{\mathrm{b}}$ \\
\hline C20:1n-9 & $3.25 \pm 0.28^{\mathrm{a}}$ & $1.89 \pm 0.61^{\mathrm{b}}$ & $2.80 \pm 1.14^{\mathrm{ab}}$ & $3.31 \pm 0.30^{\mathrm{a}}$ \\
\hline C22:1n-9 & $2.48 \pm 0.14^{\mathrm{a}}$ & $1.31 \pm 0.43^{\mathrm{b}}$ & $1.85 \pm 0.10^{c}$ & $1.98 \pm 0.33^{\mathrm{c}}$ \\
\hline $\mathrm{C} 24: 1 \mathrm{n}-9$ & $0.86 \pm 0.08^{\mathrm{a}}$ & $0.82 \pm 0.26^{\mathrm{a}}$ & $0.33 \pm 0.03^{b}$ & $0.37 \pm 0.07^{b}$ \\
\hline$\Sigma$ MUFA & $32.02 \pm 0.70^{\mathrm{a}}$ & $30.16 \pm 2.72^{\mathrm{a}}$ & $32.70 \pm 1.95^{\mathrm{a}}$ & $36.08 \pm 1.68^{b}$ \\
\hline C18:2n-6 (LA) & $1.31 \pm 0.51^{\mathrm{ab}}$ & $1.05 \pm 0.11^{\mathrm{b}}$ & $1.61 \pm 0.02^{\mathrm{a}}$ & $1.58 \pm 0.04^{\mathrm{a}}$ \\
\hline C18:3n-6 (GLA) & $0.17 \pm 0.05^{\mathrm{a}}$ & $0.16 \pm 0.09^{a}$ & $0.20 \pm 0.06^{a}$ & $0.11 \pm 0.06^{\mathrm{a}}$ \\
\hline C18:3n-3 (ALA) & $0.58 \pm 0.26^{\mathrm{a}}$ & $0.34 \pm 0.07^{\mathrm{a}}$ & $0.43 \pm 0.25^{\mathrm{a}}$ & $0.40 \pm 0.23^{\mathrm{a}}$ \\
\hline $\mathrm{C} 20: 2 \mathrm{n}-6$ & $0.20 \pm 0.02^{\mathrm{a}}$ & $0.09 \pm 0.16^{\mathrm{a}}$ & $0.21 \pm 0.20^{\mathrm{ab}}$ & $0.03 \pm 0.05^{\mathrm{a}}$ \\
\hline$C 20: 3 n-6$ & $0.11 \pm 0.01^{\mathrm{a}}$ & $0.02 \pm 0.04^{\mathrm{b}}$ & $0.12 \pm 0.07^{\mathrm{a}}$ & $0.08 \pm 0.06^{\mathrm{ab}}$ \\
\hline C20:3n-3 & $0.05 \pm 0.04^{\mathrm{a}}$ & $0.00 \pm 0.00^{\mathrm{b}}$ & $0.04 \pm 0.03^{\mathrm{ab}}$ & $0.01 \pm 0.02^{\mathrm{ab}}$ \\
\hline C20:4n-6 (ARA) & $0.42 \pm 0.03^{\mathrm{a}}$ & $0.32 \pm 0.07^{b}$ & $0.40 \pm 0.03^{\mathrm{a}}$ & $0.42 \pm 0.02^{\mathrm{a}}$ \\
\hline C20:5n-3 (EPA) & $10.73 \pm 0.40^{\mathrm{a}}$ & $13.08 \pm 1.31^{b}$ & $10.79 \pm 0.22^{\mathrm{a}}$ & $10.81 \pm 0.38^{a}$ \\
\hline $\mathrm{C} 22: 2 \mathrm{n}-6$ & $0.27 \pm 0.00^{\mathrm{a}}$ & $0.31 \pm 0.04^{\mathrm{a}}$ & $0.41 \pm 0.01^{b}$ & $0.38 \pm 0.02^{\mathrm{b}}$ \\
\hline$C 22: 5 n-3$ & $1.60 \pm 0.10^{\mathrm{a}}$ & $2.24 \pm 0.25^{\mathrm{b}}$ & $2.17 \pm 0.07^{b}$ & $2.01 \pm 0.15^{b}$ \\
\hline C22:6n-3 (DHA) & $18.17 \pm 1.26^{\mathrm{a}}$ & $18.27 \pm 4.53^{\mathrm{a}}$ & $9.25 \pm 0.39^{\mathrm{b}}$ & $9.42 \pm 0.88^{\mathrm{b}}$ \\
\hline DHA/EPA & $1.69 \pm 0.06^{\mathrm{a}}$ & $1.42 \pm 0.43^{\mathrm{a}}$ & $0.86 \pm 0.02^{\mathrm{b}}$ & $0.87 \pm 0.05^{\mathrm{b}}$ \\
\hline$\Sigma$ PUFA & $33.62 \pm 1.43^{\mathrm{a}}$ & $35.87 \pm 4.09^{\mathrm{a}}$ & $25.63 \pm 0.64^{\mathrm{b}}$ & $25.25 \pm 1.59^{\mathrm{b}}$ \\
\hline इn-3 PUFA & $31.13 \pm 1.78^{\mathrm{a}}$ & $33.93 \pm 4.36^{\mathrm{a}}$ & $22.68 \pm 0.71^{b}$ & $22.65 \pm 1.53^{\mathrm{b}}$ \\
\hline Lipid & $5.82 \pm 1.16^{\mathrm{a}}$ & $2.61 \pm 1.10^{\mathrm{b}}$ & $5.97 \pm 0.64^{\mathrm{a}}$ & $5.00 \pm 1.03^{\mathrm{a}}$ \\
\hline
\end{tabular}

Editorial responsibility: John Piatt, Anchorage, Alaska, USA
Submitted: August 24, 2009; Accepted: January 5, 2010 Proofs received from author(s): April 16, 2010 